Prepared for the U.S. Department of Energy

under Contract DE-AC05-76RL01830

\title{
Evaluating greenhouse gas emissions from hydropower complexes on large rivers in Eastern Washington
}

\section{FINAL REPORT}

$\begin{array}{ll}\text { EV Arntzen } & \text { S Niehus } \\ \text { BL Miller } & \text { M Richmond } \\ \text { AC O'Toole } & \end{array}$

March 2013

Pacific Northwest

NATIONAL LABORATORY

Proudly Operated by Battelle Since 1965 


\title{
DISCLAIMER
}

This report was prepared as an account of work sponsored by an agency of the United States Government. Neither the United States Government nor any agency thereof, nor Battelle Memorial Institute, nor any of their employees, makes any warranty, express or implied, or assumes any legal liability or responsibility for the accuracy, completeness, or usefulness of any information, apparatus, product, or process disclosed, or represents that its use would not infringe privately owned rights. Reference herein to any specific commercial product, process, or service by trade name, trademark, manufacturer, or otherwise does not necessarily constitute or imply its endorsement, recommendation, or favoring by the United States Government or any agency thereof, or Battelle Memorial Institute. The views and opinions of authors expressed herein do not necessarily state or reflect those of the United States Government or any agency thereof.

\author{
PACIFIC NORTHWEST NATIONAL LABORATORY \\ operated by \\ BATTELLE \\ for the \\ UNITED STATES DEPARTMENT OF ENERGY \\ under Contract DE-AC05-76RL01830 \\ Printed in the United States of America
Available to DOE and DOE contractors from the
Office of Scientific and Technical Information,
P.O. Box 62, Oak Ridge, TN 37831-0062;
ph: (865) 576-8401
fax: $(865)$ 576-5728
email: reports@adonis.osti.gov

Available to the public from the National Technical Information Service

5301 Shawnee Rd., Alexandria, VA 22312

ph: (800) 553-NTIS (6847)

email: orders@intis.gov $<$ http://www.ntis.gov/about/form.aspx $>$

Online ordering: http://www.ntis.gov

This document was printed on recycled paper. 


\title{
Evaluating greenhouse gas emissions from hydropower complexes on large rivers in Eastern Washington
}

\author{
EV Arntzen S Niehus \\ BL Miller M Richmond \\ AC O'Toole
}

March 2013

Prepared for

U.S. Department of Energy

under Contract DE-AC05-76RL01830

Pacific Northwest National Laboratory

Richland, Washington 99352 



\section{Abstract}

Inland water bodies, such as freshwater lakes, are known to be net emitters of carbon dioxide $\left(\mathrm{CO}_{2}\right)$ and methane $\left(\mathrm{CH}_{4}\right)$. In recent years, significant greenhouse gas $(\mathrm{GHG})$ emissions from tropical, boreal, and mid-latitude reservoirs have also been reported. At a time when hydropower is increasing worldwide, better understanding of seasonal and regional variation in GHG emissions is needed in order to develop a predictive understanding of such fluxes within man-made impoundments. We examined reservoir impoundments created by power-producing dam complexes within xeric temperate locations in the northwestern United States. Sampling environments on the Snake (Lower Monumental Dam Complex) and Columbia Rivers (Priest Rapids Dam Complex) included tributary, mainstem, embayment, forebay, and tailrace areas during winter and summer 2012. At each sampling location, GHG measurements included multiple exchange pathways: surface gas flux, degassing as water passed through dams during power generation, ebullition within littoral embayments, and direct sampling of hyporheic porewater. Measurements were also carried out in a free-flowing reach of the Columbia River (the Hanford Reach) to estimate unaltered conditions. Surface flux resulted in very low emissions, with reservoirs acting as a sink for $\mathrm{CO}_{2}$ (up to $-262 \mathrm{mg} \mathrm{m}^{-2} \mathrm{~d}^{-1}$, which is within the range previously reported for similarly located reservoirs). Surface flux of $\mathrm{CH}_{4}$ remained below $1 \mathrm{mg}$ $\mathrm{CH}_{4} \mathrm{~m}^{-2} \mathrm{~d}^{-1}$, a value well below fluxes reported previously for temperate reservoirs. Water passing through hydroelectric projects acted as a sink for $\mathrm{CO}_{2}$ during winter and a small source during summer, with mean degassing fluxes of -117 and $4.5 \mathrm{t} \mathrm{CO}_{2} \mathrm{~d}^{-1}$, respectively. Degassing of $\mathrm{CH}_{4}$ was minimal, with mean fluxes of $3.1 \times 10^{-6}$ and $-5.6 \times 10^{-4} \mathrm{t} \mathrm{CH}_{4} \mathrm{~d}^{-1}$ during winter and summer, respectively. Gas efflux due to ebullition was greater in coves located within reservoirs than in coves within the free flowing Hanford Reach, and $\mathrm{CH}_{4}$ efflux exceeded that of $\mathrm{CO}_{2}$. $\mathrm{CH}_{4}$ ebullition varied widely across sampling locations, ranging from 10.5 to $1039 \mathrm{mg} \mathrm{CH}_{4}$ $\mathrm{m}^{-2} \mathrm{~d}^{-1}$, with mean fluxes of $324 \mathrm{mg} \mathrm{CH}_{4} \mathrm{~m}^{-2} \mathrm{~d}^{-1}$ in Lower Monumental Dam reservoir and 482 $\mathrm{mg} \mathrm{CH}_{4} \mathrm{~m}^{-2} \mathrm{~d}^{-1}$ in the Priest Rapids Dam reservoir. The magnitude of $\mathrm{CH}_{4}$ efflux due to ebullition was relatively high, falling within the range recently reported for other temperate reservoirs around the world, further suggesting that this $\mathrm{CH}_{4}$ source should be considered in estimates of global greenhouse gas emissions. Methane flux from sediment pore-water within littoral embayments averaged $4.2 \mathrm{mg} \mathrm{m}^{-2} \mathrm{~d}^{-1}$ during winter and $8.1 \mathrm{mg} \mathrm{m}^{-2} \mathrm{~d}^{-1}$ during summer, with a peak flux of $19.8 \mathrm{mg} \mathrm{m}^{-2} \mathrm{~d}^{-1}$ (at the same location where $\mathrm{CH}_{4}$ ebullition was also the greatest). Carbon dioxide flux from sediment pore-water averaged approximately $80 \mathrm{mg} \mathrm{m}^{-2} \mathrm{~d}^{-1}$ with little difference between winter and summer. Similar to emissions from ebullition, flux from sediment pore-water was higher in reservoirs than in the free flowing reach. The findings reported in this investigation are consistent with recent discoveries of substantial $\mathrm{CH}_{4}$ emissions from temperate Swiss and Chinese reservoirs. There is an apparent global need to better understand $\mathrm{CH}_{4}$ emissions from littoral embayments of temperate hydroelectric reservoirs when estimating the impact of $\mathrm{CH}_{4}$ emissions on climate change. 



\section{Acknowledgments}

Arthur Stewart, Mark Bevelhimer, Jennifer Mosher, Jana Phillips, and Allison Fortner (Oak Ridge National Laboratory) provided guidance and advice through all phases of the project. Mark Reller and Janelle Schmidt (Bonneville Power Administration), Gregg Carrington and Janel Duffy (Chelan County Public Utilities District), Tom Kahler (Douglas County Public Utility District), Tom Dresser (Grant County Public Utility District), Kimberly Johnson, Brad Bird, and Rebecca Weiss (U.S. Army Corps of Engineers), and Eric Corbin (U.S. Bureau of Reclamation) served on an advisory group that helped identify important regional issues and assisted with reservoir selection. Kenneth Ham and Katherine Klett (PNNL) assisted with project implementation. Tom Resch (PNNL) completed carbon analyses. Chris Thompson (PNNL) supervised gas chromatography analyses. Brenda Ben James (Cascade Aquatics LLC) helped collect field samples. This work was supported by the U.S. Department of Energy, Office of Energy Efficiency and Renewable Energy_Wind and Water Power Program. Pacific Northwest National Laboratory is operated by Battelle for the U.S. Department of Energy under Contract DE-AC05-76RL01830. 



\section{Contents}

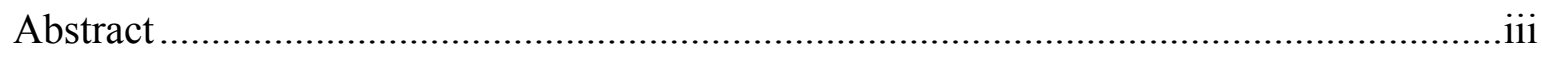

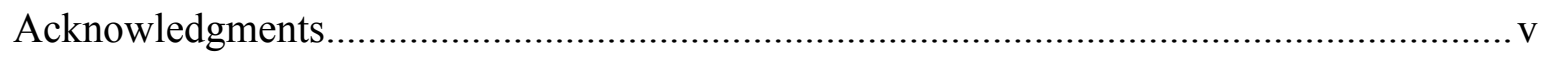

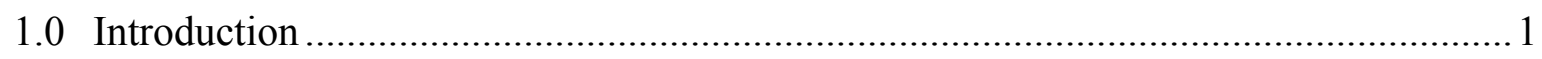

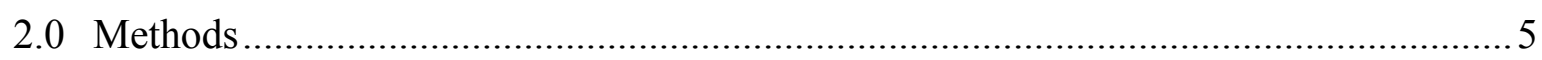

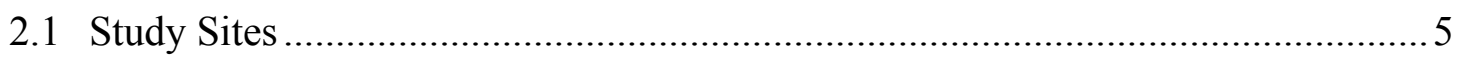

2.2 Experimental Methods: .................................................................................. 6

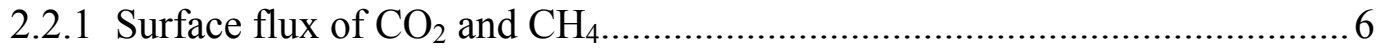

2.2.2 Depth-discreet and continuous water quality monitoring ......................... 8

2.2.3 Degassing of $\mathrm{CO}_{2}$ and $\mathrm{CH}_{4}$ through hydroelectric turbines ....................... 9

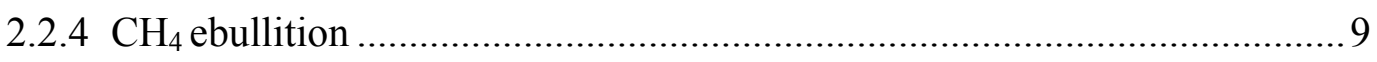

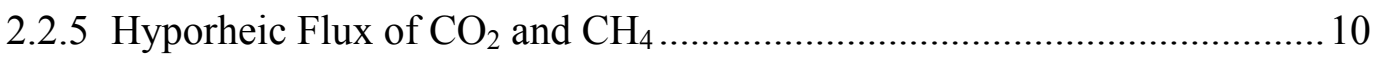

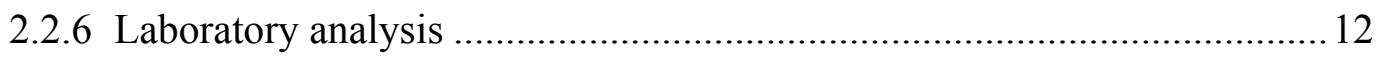

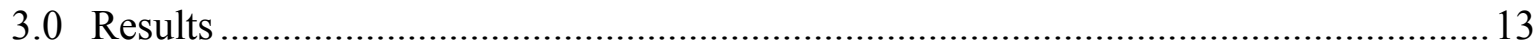

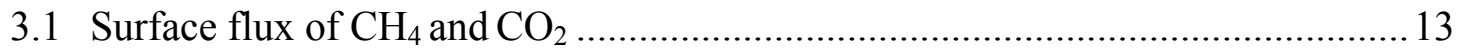

3.2 Degassing of $\mathrm{CH}_{4}$ and $\mathrm{CO}_{2}$ at hydroelectric dam projects .............................. 14

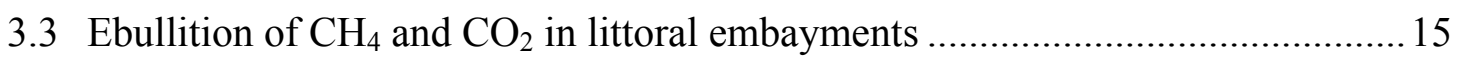

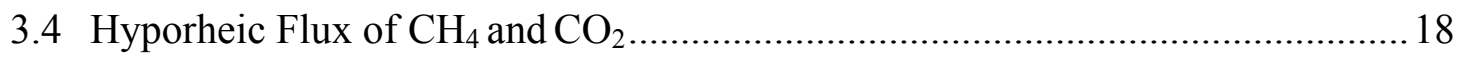

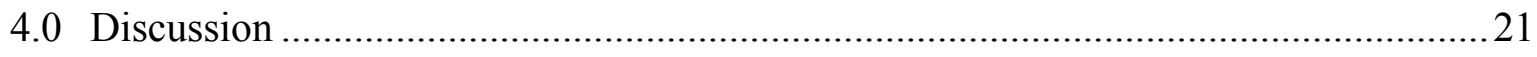

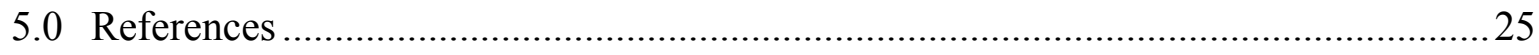




\section{Figures}

Figure 1. Greenhouse gas emissions were measured from the forebay, tailrace, mainstem reservoir, tributaries, and embayments within the Priest Rapids (PRD) and Lower Monumental Dam (LMN) complexes and from embayment and mainstem locations within the Hanford Reach, a free flowing stretch of the Columbia River. Embayments (white squares) were sampled using inverted funnel samplers to trap gas bubbles in surface water and using piezometers to sample sediment pore-water. Samples were collected from the mainstem river adjacent to each embayment.

Figure 2. Surface water flux for A) $\mathrm{CH}_{4}$ and $\mathrm{B}$ ) $\mathrm{CO}_{2}$ across sampling environments in the Hanford Reach (HR), Priest Rapids hydroelectric dam complex (PRD), and Lower Monumental hydroelectric dam complex (LMN). Solid horizontal lines within each box represent median flux, dashed lines within each box represent mean flux, ends of boxes represent the $25^{\text {th }}$ and $75^{\text {th }}$ percentiles and black dots represent outliers.

Figure 3. Degassing flux values for $\mathrm{A}) \mathrm{CH}_{4}\left(\mathrm{td}^{-1}\right)$ and $\left.\mathrm{B}\right) \mathrm{CO}_{2}\left(\mathrm{td}^{-1}\right)$ across hydroelectric dam projects in March 2012 and September 2012. Solid horizontal lines within each box represent median flux, dashed horizontal lines represent mean flux, and ends of boxes represent the $25^{\text {th }}$ and $75^{\text {th }}$ percentile.

Figure 4. Gas concentration values $\left(\mathrm{mgL}^{-1}\right)$ for $\left.\mathrm{A}\right) \mathrm{CH}_{4}$ and $\left.\mathrm{B}\right) \mathrm{CO}_{2}$ gas samples collected in funnels from all littoral embayments during September 2012. Solid horizontal lines within each box represent median concentration, dashed lines within each box represent mean concentration, ends of boxes represent the $25^{\text {th }}$ and $75^{\text {th }}$ percentiles and black dots represent outliers.

Figure 5. Flux values ( $\mathrm{mg} \mathrm{m}^{-2} \mathrm{~d}^{-1}$ ) for A) $\mathrm{CH}_{4}$ and B) $\mathrm{CO}_{2}$ gas samples collected using inverted funnel samplers with littoral cove sampling environments in the Hanford Reach (HR), Priest Rapids hydroelectric dam complex (PRD), and Lower Monumental hydroelectric dam complex (LMN) during September 2012. Solid horizontal lines within each box represent median flux, dashed lines within each box represent mean flux, ends of boxes represent the $25^{\text {th }}$ and $75^{\text {th }}$ percentiles and black dots represent outliers

Figure 6. Porewater flux of A) $\mathrm{CH} 4\left(\mathrm{mg} \mathrm{m}^{-2} \mathrm{~d}^{-1}\right)$ and $\left.\mathrm{B}\right) \mathrm{CO}_{2}\left(\mathrm{mg} \mathrm{m}^{-2} \mathrm{~d}^{-1}\right)$ in littoral bays aross all study regions during March 2012 and September 2012. Solid horizontal lines within each box represent median flux, dashed horizontal lines within each box represent mean flux, and ends of boxes represent the $25^{\text {th }}$ and $75^{\text {th }}$ percentiles.

Figure 7. Porewater flux for A) $\mathrm{CH}_{4}\left(\mathrm{mg} \mathrm{m}^{-2} \mathrm{~d}^{-1}\right)$ and B) $\mathrm{CO}_{2}\left(\mathrm{mg} \mathrm{m}^{-2} \mathrm{~d}^{-1}\right)$ in littoral bays within the Hanford Reach (HR), Priest Rapids hydroelectric dam complex (PRD), and Lower Monumental hydroelectric dam complex (LMN) in March and September 2012. Solid horizontal lines within each box represent median flux, dashed lines represent mean flux, and ends of boxes represent the $25^{\text {th }}$ and $75^{\text {th }}$ percentiles....

Figure 8. DOC versus $\mathrm{CH}_{4}$ (porewater flux and surface flux combined) for all three regions during September 2012 


\section{Tables}

Table 1. Porosity values for various substrates determined using grainsize distributions found in greatest proportion at each littoral embayment, together with the relationship presented by Stephens et al. (1998).........................................................11 



\subsection{Introduction}

Atmospheric concentrations of carbon dioxide $\left(\mathrm{CO}_{2}\right)$ have risen from 315 parts per million (ppm) in 1959 to 385 ppm today (IPCC 2007; Taub 2010). The Intergovernmental Panel on Climate Change (IPCC 2007) projects that atmospheric $\mathrm{CO}_{2}$ concentrations will increase to between 500 and 1000 ppm by 2100, raising questions about how this will effect carbon (C) cycling between the atmosphere and hydrosphere (Taub 2010). $\mathrm{CO}_{2}$ supersaturation in freshwater lakes relative to atmospheric concentrations has been widely documented, implicating inland waters as one source of this greenhouse gas (GHG) to the atmospheric sink (Cole et al. 1994). Furthermore, Butman et al. (2012) has shown several temperate and Arctic rivers to be saturated with $\mathrm{CO}_{2}$ in excess of atmospheric levels. At the same time, researchers have become increasingly aware of the extent to which the greenhouse gases $\mathrm{CO}_{2}$ and methane $\left(\mathrm{CH}_{4}\right)$ may be produced within the lacustrine environments created by hydroelectric dam complexes. As a $\mathrm{GHG}, \mathrm{CH}_{4}$ has a warming potential in the atmospheric sink that is approximately 25 times greater than $\mathrm{CO}_{2}$ per 100 years (Forster et al. 2007). Consequently, hydroelectricity's longpresumed carbon neutrality has been increasingly re-examined (Bastviken et al. 2004; Soumis et al. 2004; Tremblay et al. 2005).

With only $17 \%$ of potential hydroelectric sites utilized globally, dam construction is on the rise in developing countries (Bednarek 2001; Barros et al. 2011). In recent years, sizeable GHG efflux from newly constructed hydroelectric dam reservoirs in tropical and boreal latitudes has been measured, and efforts have been made to effectively model emissions (Huttunen et al. 2002; Santos et al. 2005; Tremblay et al. 2005; Galy-Lacaux et al. 1997; Barros et al. 2011). However, $\mathrm{CO}_{2}$ and $\mathrm{CH}_{4}$ flux rates vary among these studies by orders of magnitude. Furthermore, there is uncertainty regarding the relative contribution of greenhouse gases from reservoirs in temperate latitudes. For example, Barros et al. (2011) found that reservoir GHG emissions decreased with reservoir age and distance from the equator. This conflicts with the relatively recent discovery of "extreme" $\mathrm{CH}_{4}$ emissions ( $>150 \mathrm{mg} \mathrm{m}^{-2} \mathrm{~d}^{-1}$ ) from a temperate latitude Swiss reservoir that is 90 years old (Del Sontro et al. 2010).

Hydroelectric dams alter riverine systems to create lacustrine conditions, and block the downstream transport of organic and inorganic C (Wetzel 2001; Bastviken et al. 2004). In addition to dissolved inorganic carbon, which may occur as $\mathrm{CO}_{2}$, rivers export dissolved and particulate organic carbon (DOC and POC) from throughout their catchments. While this DOC

and POC may be respired by aerobic heterotrophs to produce $\mathrm{CO}_{2}, \mathrm{POC}$ accumulations in littoral embayments of hydroelectric dam complexes can also become anoxic substrates for methanogenesis (Wetzel 2001; Del Sontro et al. 2010; Butman et al. 2012). Additionally, methanogensis can take place in the hyporheic zone, the shallow subsurface zone of streambeds where microbial activity and anoxia can prevail within pore-waters (Schindler and Krabbenhoft 1998; Huttunen et al. 2006). Under low hydrostatic pressures (e.g., when surface water depths are less than $10 \mathrm{~m}$ ), hyporheic $\mathrm{CH}_{4}$ can rise to the surface in large, ebullated bubbles (Del Sontro et al. 2010). 
Previous studies within temperate reservoirs of the United States report varying exchange of $\mathrm{CO}_{2}$ and $\mathrm{CH}_{4}$ with the atmosphere via surface flux. Soumis et al. (2004) evaluated six reservoirs in Washington and California during September 2001, and concluded that four were sinks for $\mathrm{CO}_{2}$ and all were emitters of $\mathrm{CH}_{4}$ (3.2 to $\left.9.5 \mathrm{mg} \mathrm{m}^{-2} \mathrm{~d}^{-1}\right)$. Working in reservoirs located in semiarid Utah, Arizona, and New Mexico, Therrien et al. (2005) reported mean $\mathrm{CO}_{2}$ emissions of 664 $\mathrm{mg} \mathrm{CO} \mathrm{m}^{-2} \mathrm{~d}^{-1}$. In still another study, St. Louis et al. (2000) listed $\mathrm{CO}_{2}$ and $\mathrm{CH}_{4}$ emissions in three of five Wisconsin reservoirs ( 3 to $11 \mathrm{mg} \mathrm{CH}_{4} \mathrm{~m}^{-2} \mathrm{~d}^{-1}$ and 220 to $1300 \mathrm{mg} \mathrm{CO}_{2} \mathrm{~m}^{-2} \mathrm{~d}^{-1}$ ). All of these studies evaluated surface emissions only and were focused in the mainstem environments of reservoirs. Recent results show $\mathrm{CO}_{2}$ surface efflux for Tennessee's Lake Douglas was generally within the range reported by the IPCC for other, moist temperate reservoirs $\left(<0\right.$ to $\left.6.00 \mathrm{E}+03 \mathrm{mg} \mathrm{m}^{-2} \mathrm{~d}^{-1}\right)$, while $\mathrm{CH}_{4}$ surface efflux was generally similar to previous results for the temperate United States $\left(<10 \mathrm{mg} \mathrm{m}^{-2} \mathrm{~d}^{-1}\right)$, although emissions were much greater, exceeding $50 \mathrm{mg} \mathrm{m}^{-2} \mathrm{~d}^{-1}$ in Nolichucky Cove, a local littoral embayment (Mulholland et al. 2010).

Hydroelectric dam complexes include many distinct environments, including tributaries, littoral embayments, the hyporheic zone, the mainstem reservoir, the forebay, and the tailrace. The dynamics related to GHG emissions are known to vary spatially and temporally across these environs (IHA 2010). While GHG emissions from the surface of hydroelectric reservoirs and from water passing through hydroelectric projects (i.e., outgassing) have been documented, studies of GHG fluxes from the littoral environments associated with these projects are less represented (Chen et al. 2009; Del Sontro et al. 2010, Mulholland et al. 2010). Understanding such littoral fluxes is important, especially since they have been previously underestimated in studies of temperate hydroelectric dam complexes (Chen et al. 2009). For example, littoral embayments occupy $10 \%$ of surface area in the impoundment created by the Three Gorges

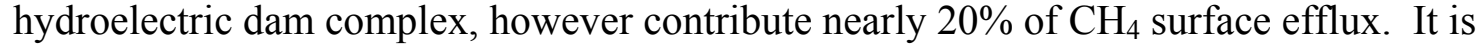
generally accepted that $\mathrm{CH}_{4}$ efflux occurs from vegetated littoral embayments of small boreal streams, where the vascular tissues of emergent macrophytes convey dissolved $\mathrm{CH}_{4}$ directly from anoxic substrates to the atmosphere (Kelker and Chanton 1997; Juutinen et al. 2003; Kankaala et al. 2004; Bergstrom 2007). These studies estimate that $\mathrm{CH}_{4}$ efflux per unit area is highest in such vegetated littoral embayments, but do not sample from or provide data on $\mathrm{CH}_{4}$ fluxes from large temperate rivers impounded by hydroelectric dams (Kelker and Chanton 1997; Juutinen et al. 2003; Kankaala et al. 2004; Bergstrom 2007).

In order to provide greater understanding of the spatial and temporal resolution of GHG flux from the temperate United States reservoirs it regulates, the U.S. Department of Energy (DOE) initiated a study of Southeastern U.S. reservoirs (Mulholland et al. 2010). The Wind and Water Power Program of the Office of Energy Efficiency and Renewable Energy (U.S. DOE) recently expanded this evaluation to include reservoirs in the Pacific Northwest region of the United States. Pacific Northwest National Laboratory (PNNL) conducted field sampling of representative reservoirs from this region and estimated GHG emissions. The goals of PNNL's field program included 1) measurement of expected emissions pathways at sufficient temporal frequency and spatial density, 2) collection of data from hydroelectric dam complexes that are 
regionally representative, and 3) study of pre-impoundment proxies, such as tributaries and remaining free-flowing reaches to approximate net emissions (Mulholland et al. 2010).

Ultimately, such data are needed to develop a predictive understanding of gas fluxes within manmade hydroelectric dam complexes.

The objectives of PNNL's study were to contribute to the Department of Energy's national effort by sampling Northwest reservoirs in order to 1) determine whether $\mathrm{CO}_{2}$ and $\mathrm{CH}_{4}$ emissions varied among different environments within representative hydroelectric dam complexes on the Columbia and Snake Rivers in Washington and 2) estimate GHG fluxes from those environments while placing them in context relative to GHG emissions from other temperate hydroelectric dam complexes. 



\subsection{Methods}

\subsection{Study Sites}

Study locations were in xeric Eastern Washington, and included Priest Rapids on the midColumbia River and Lower Monumental on the lower Snake River. We sampled both of these hydroelectric dam complexes, with generating capacities of 955.6 MW and 810 MW, respectively (CBR 2013). Additionally, one free-flowing reach (the Hanford Reach) of the Columbia River was sampled. Field efforts at all locations occurred during March and September, 2012. The Priest Rapids complex (Priest Rapids Lake) has a residence time of 0.8 days and a surface area of $31.3 \mathrm{~km}^{2}$ (ORNL 2013). Mean annual discharge through Priest Rapids Dam (for the time period 2002-2011) is approximately $3,115 \mathrm{~m}^{3} \mathrm{~s}^{-1}$ (USGS 2013). The Priest Rapids Dam reservoir is characterized by several embayments and agricultural (i.e., nutrient) inputs, one tributary (Crab Creek). Pre-impoundment conditions may be approximated by sampling the free flowing Hanford Reach, downstream from the dam (Figure 1). The Lower Monumental Dam complex (Lake Herbert G. West) has a residence time of 6 days and a surface area of $26.7 \mathrm{~km}^{2}$ (ORNL 2013). Mean annual discharge through Lower Monumental Dam (for the time period 2003-2012) is approximately $1,410 \mathrm{~m}^{3} \mathrm{~s}^{-1}$ (DART 2013). The Lower Monumental Dam reservoir also has many embayments and agricultural inputs, and its tributaries include the Palouse and Tucannon Rivers. Both reservoirs are generally oxic, with winter temperatures dropping well below $5^{\circ} \mathrm{C}$ and summer temperatures approaching $20^{\circ} \mathrm{C}$ in the Priest Rapids Dam complex and often exceeding $20^{\circ} \mathrm{C}$ in the Lower Monumental Dam complex (DART 2013). The areas we studied were generally not nutrient limited. Summer concentrations ranged from 0 to $0.47 \mathrm{mg} \mathrm{L}^{-1} \mathrm{PO}_{4}{ }^{3-}$ and from 0.6 to $1.9 \mathrm{mg} \mathrm{L}^{-1} \mathrm{NO}_{3}{ }^{-}$along the Hanford Reach, from 0.02 to $1.64 \mathrm{mg} \mathrm{L}^{-1} \mathrm{PO}_{4}{ }^{3-}$ and from 0.8 to $5.5 \mathrm{mg} \mathrm{L}^{-1} \mathrm{NO}_{3}{ }^{-}$at Priest Rapids, and from 0.28 to $2.75 \mathrm{mg} \mathrm{L}^{-1} \mathrm{PO}_{4}{ }^{3-}$ and from 0.1 to $4.3 \mathrm{mg} \mathrm{L}^{-1} \mathrm{NO}_{3}{ }^{-}$in the Lower Monumental complex. Although none of our study locations represented anoxic conditions, some reservoirs in the Pacific Northwest are known to contain seasonally anoxic environments (e.g., the Snake River's Brownlee complex; Nuernberg 2004). Both hydro projects participate in spring spill operations to aid migratory juvenile fish, a unique and important characteristic of many Pacific Northwest dam complexes, which may enhance outgassing in the tailrace. The selected hydroelectric dam complexes are fairly representative of regional hydroelectric dam complexes east of the Cascade Range, in semi-arid Washington. Within Priest Rapids and Lower Monumental reservoirs, at least one major tributary, two embayment sites, two mainstem reservoir sites, two forebay sites, and two tailrace sites were sampled (Figure 1). Additionally, two embayment sites and two mainstem reservoir sites were sampled along the free-flowing Hanford Reach (Figure 1). 


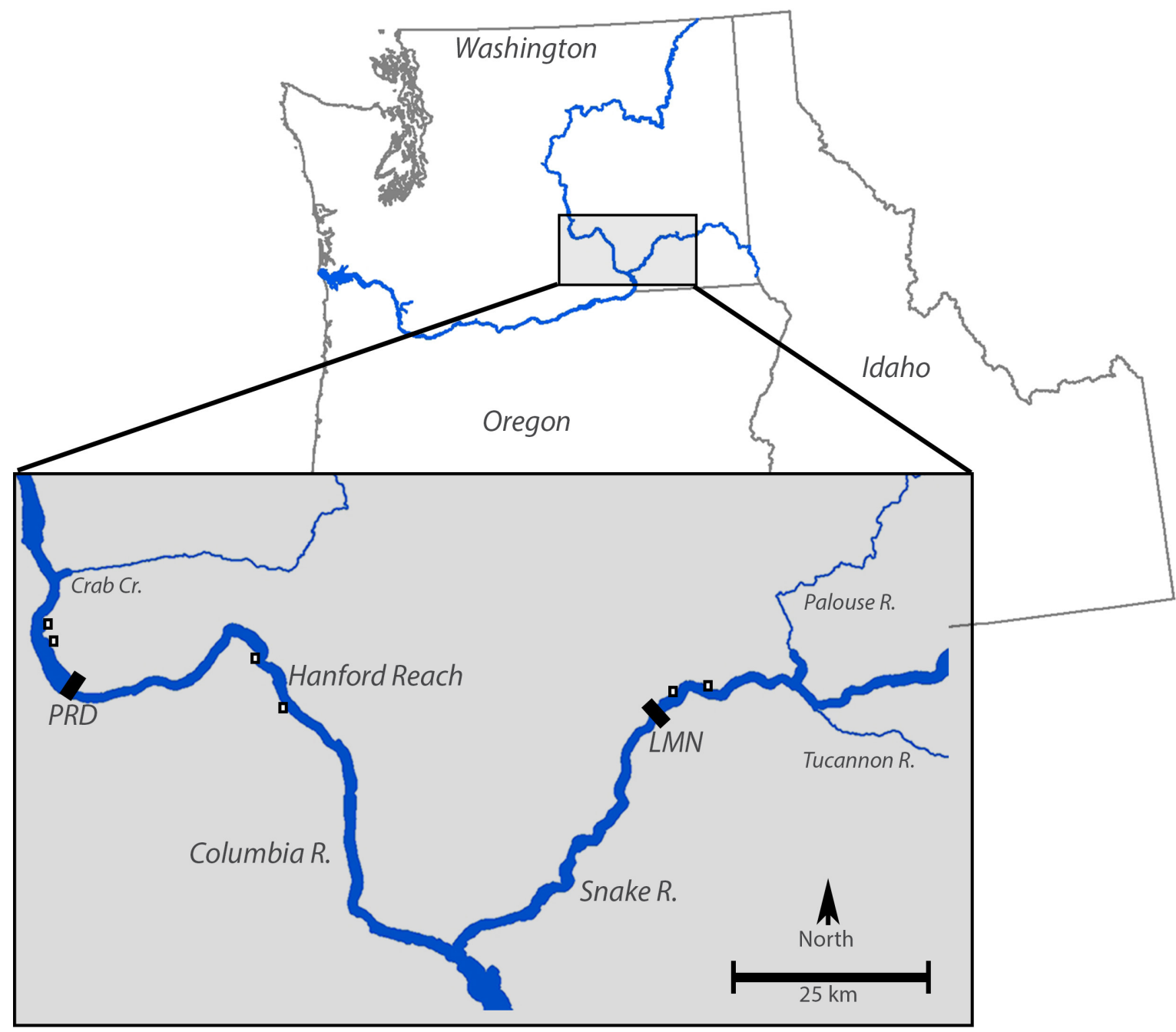

Figure 1. Greenhouse gas emissions were measured from the forebay, tailrace, mainstem reservoir, tributaries, and embayments within the Priest Rapids (PRD) and Lower Monumental Dam (LMN) complexes and from embayment and mainstem locations within the Hanford Reach, a free flowing stretch of the Columbia River. Embayments (white squares) were sampled using inverted funnel samplers to trap gas bubbles in surface water and using piezometers to sample sediment pore-water. Samples were collected from the mainstem river adjacent to each embayment.

\subsection{Experimental Methods:}

\subsubsection{Surface flux of $\mathrm{CO}_{2}$ and $\mathrm{CH}_{4}$}

At all sites, $7 \mathrm{~mL}$ of water was sampled via syringe at $0.01 \mathrm{~m}$ and injected into $10 \mathrm{~mL}$ evacuated glass vials to equilibrate with $3 \mathrm{~mL}$ of headspace. The same procedure was used to 
collect an ambient air sample. Additional samples were gathered using syringes and a gas tight Van Dorn sampler (Wildco Alpha Horizontal 3.2 L) at $1 \mathrm{~m}$ and other depths to show relative saturation to atmospheric concentrations of $\mathrm{CO}_{2}$ and $\mathrm{CH}_{4}$. All vials contained $0.4 \mathrm{~g}$ potassium chloride $(\mathrm{KCl})$ to both inhibit further respiration and prevent partitioning of the sampled gas between headspace and water (IHA 2010). Vials were sealed with a butyl rubber stopper and an outer centrifuge tube containing DI water, and were refrigerated until analysis by gas chromatography (GC). When vials were held for extended periods, helium (He) gas was injected into the headspace vial as an additional seal. Flux at the surface of waters at all sites was calculated in September using the thin boundary layer equation, as presented by Duchemin et al. (1999), Roehm and Tremblay (2006), and Del Sontro et al. (2010):

$$
F_{\text {Surface }}=K_{i}\left(C_{w}-C_{e q}\right)
$$

Where $F_{\text {Surface }}$ is GHG flux, $K_{i}$ is the gas exchange coefficient, $C_{w}$ is the partial pressure of $\mathrm{CO}_{2}$ and $\mathrm{CH}_{4}(\mathrm{~atm})$ in water (measured directly at $0.01 \mathrm{~m}$ depth), and $C_{e q}$ is the atmospheric equilibrium partial pressure of $\mathrm{CO}_{2}$ and $\mathrm{CH}_{4}(\mathrm{~atm})$. The gas exchange coefficient, $K_{i}$, was determined using the following relationships (Wanninkhof 1992; MacIntyre et al. 1995; Cole and Caraco 1998; Crusius and Wanninkhof 2003; Del Sontro et al. 2010; IHA 2010):

$$
\begin{aligned}
& K_{i}=K_{600}(S c / 600)^{-0.66} \\
& K_{600}\left(C O_{2}\right)=2.07+0.215 U_{10}^{1.7} \\
& K_{600}=\left(C H_{4}\right)=0.45 U_{10}^{1.64} \\
& U_{10}=U_{1} 1.22 \\
& S c=a-b T+c T^{2}-d T^{3}
\end{aligned}
$$

Where $U_{10}$ is wind speed at $10 \mathrm{~m}$ above the water's surface; this value was converted from wind speed measured at $2 \mathrm{~m}$ above the water's surface $\left(U_{l}\right)$ as outlined in Wanninkhof (1992). $\mathrm{Sc}$ is the Schmidt number, or the ratio of momentum diffusivity and mass diffusivity as presented by Jaehne et al. (1987) and Wanninkhof (1992), $T$ is the temperature $\left({ }^{\circ} \mathrm{C}\right)$, and $a, b, c$, and $d$ are constants for $\mathrm{CO}_{2}$ and $\mathrm{CH}_{4}$ (Wanninkhof 1992; IHA 2010). The partial pressures of $\mathrm{CO}_{2}$ and $\mathrm{CH}_{4}$ in water $\left(C_{w}\right)$ and in the atmosphere $\left(C_{e q}\right)$ were determined using the following relationships:

$$
\begin{aligned}
& C_{w}=P_{i} K_{H} \\
& C_{e q}=P_{i} K_{0} \\
& P_{i}=\left(n_{i} / n_{T}\right) P_{T}
\end{aligned}
$$


Where $\mathrm{P}_{\mathrm{i}}$ is the partial pressure of $\mathrm{CO}_{2}$ or $\mathrm{CH}_{4}$, respectively, $n_{i} / n_{T}$ is the mole fraction of $\mathrm{CO}_{2}$ or $\mathrm{CH}_{4}$ obtained via gas chromatography, and $P_{T}$ is the approximate atmospheric pressure at the elevation of sampling. The relationship between pressure and concentration is determined using the ideal gas law.

Both $C_{w}$ and $C_{e q}$ were corrected for temperature dependence of gas solubility in water following Henry's Law, and $C_{w}$ was further corrected for the effect of pressure due to water depth on gas solubility (Weiss 1974). These adjustments were made using the $K_{H}$ and $K_{0}$ variables, which were determined as follows (Weiss 1974; Wiesenburg and Guinasso 1979; Lide 2007; IHA 2010):

$$
\begin{aligned}
& K_{H}=K_{0} \ln \left[(1-p) \bar{v}_{i} / R T_{K}\right] \\
& \ln K_{0}\left(C O_{2}\right)=A+B\left(100 / T_{K}\right)+C \ln \left(T_{K} / 100\right)+s\left[D-E\left(T_{K} / 100\right)+F\left(T_{K} / 100\right)^{2}\right] \\
& \ln K_{0}\left(C H_{4}\right)=G+\left[H /\left(T_{K} / 100\right)\right]+I \ln \left(T_{K} / 100\right)-J\left(T_{K} / 100\right)
\end{aligned}
$$

Where $s$ is salinity $(0.025 \mathrm{ppt}), T_{K}$ is temperature in Kelvin, $P$ is the pressure of the system, $v_{i}$ is the partial molal volume of $\mathrm{CO}_{2}\left(0.03023 \mathrm{~mol} \mathrm{~L}^{-1}\right)$ and $\mathrm{CH}_{4}\left(0.03044 \mathrm{~mol} \mathrm{~L}^{-1}\right)$ in water as determined by Weiss (1974) and Yamamoto et al. (1976), respectively, and $R$ is the gas constant $\left(0.082057 \mathrm{~L} \mathrm{~atm} \mathrm{~K}^{-1} \mathrm{~mol}^{-1}\right)$. A, B, C, D, E, and $F$ are dimensionless coefficients previously used by Weiss (1974). G, H, I, and $J$ are dimensionless coefficients suggested by Lide (2007) and IHA (2010). $K_{0}$ was determined using an integrated form of the van't Hoff equation and the logarithmic Setchenow salinity dependence, first presented by Weiss (1974) for $\mathrm{CO}_{2}$ and modified by Lide (2007) for $\mathrm{CH}_{4}$.

\subsubsection{Depth-discreet and continuous water quality monitoring}

Depth-discreet water quality and the availability of nutrients were measured in order to help interpret GHG influx and efflux, and to provide information needed to select appropriate diffusion coefficients for the gases sampled. Oxidation-reduction potential (ORP), $\mathrm{pH}$, and temperature were measured at each site by deploying a data-logging water quality sonde (Hach Environmental, Loveland, Colorado) to the riverbed and slowly raising it to the river surface while logging data every second. This resulted in data collection at approximately $0.2-\mathrm{m}$ intervals, allowing for resolution of any vertical gradients present in the water column. This was investigated because $\mathrm{pH}$ fluctuates with dissolved $\mathrm{CO}_{2}$, and temperature affects gas solubility, according to Henry's Law. ORP provides insight into the oxidation of $\mathrm{CH}_{4}$, produced by anaerobic respiration in benthic interstices, to $\mathrm{CO}_{2}$ in the oxic, overlying water column, represented by the following reaction:

$$
\mathrm{CH}_{4}+2 \mathrm{O}_{2} \rightarrow \mathrm{CO}_{2}+2 \mathrm{H}_{2} \mathrm{O}
$$


Sonde measured water quality was monitored hourly in embayment areas concurrently with the deployment of ebullition funnels to 1) capture the diurnal fluctuations in DO that can occur as a result of primary production during daylight hours and 2) measure temperature (Arntzen et al. 2009). Buoys with these sondes were deployed within each embayment location in both Priest Rapids and Lower Monumental Dam complexes, as well as the Hanford Reach. Nutrient (nitrate $\left[\mathrm{NO}_{3}^{-}\right]$and phosphate $\left[\mathrm{PO}_{4}{ }^{3-}\right]$ ), dissolved oxygen (DO), and GF $45 \mu \mathrm{m}$-filtered dissolved organic carbon (DOC) samples were taken from $1 \mathrm{~m}$ and bottom depths via gastight Van Dorn sampler, and combined in a composite sample for each site. In smaller tributaries (e.g., the Tucannon River), these samples were collected from shore. Nutrients were measured in field or the laboratory using a Hach colorimeter (spectrophotometer) and associated standards (Hach Environmental, Loveland, Colorado). Upon return to the laboratory, DOC samples were refrigerated until analysis with a carbon analyzer (Model TOC-5000A, Shimadzu). All supporting data, including vertical gradients in temperature and dissolved oxygen, nutrient concentrations, and DOC were included in Appendix D.

\subsubsection{Degassing of $\mathrm{CO}_{2}$ and $\mathrm{CH}_{4}$ through hydroelectric turbines}

Degassing of $\mathrm{CO}_{2}$ and $\mathrm{CH}_{4}$ between the forebay and the tailrace were estimated using the same approach as IHA (2010):

$$
F_{D}=\left[\left(C_{w, u}-C_{w, d}\right) Q_{T}\right]+\left[\left(C_{w, u}-C_{w, d}\right) Q_{s}\right]
$$

Where $F_{D}$ is the degassing flux, $C_{w, u}$ is the concentration of $\mathrm{CO}_{2}$ and $\mathrm{CH}_{4}$ entering the dam through the forebay, $C_{w, d}$ is the concentration of $\mathrm{CO}_{2}$ and $\mathrm{CH}_{4}$ leaving the dam in the tailrace, $Q_{T}$ is the mean daily turbine discharge in $\mathrm{m}^{3} \mathrm{~s}^{-1}$, and $Q_{S}$ is the mean daily spillway discharge in $\mathrm{m}^{3} \mathrm{~s}$ ${ }^{1}$ (USACE 2012). Water samples were obtained via gas tight sampler at $1 \mathrm{~m}$. Water was sampled using the same methods in the tailrace, at $1 \mathrm{~m}$. Degassing flux headspace samples were preserved in a manner identical to surface flux headspace samples, and GC output concentrations were also adjusted for temperature and pressure dependence of solubility in water, or Henry's Law, as above $\left(K_{H}\right.$; Soumis et al. 2004).

\subsection{4 $\mathrm{CH}_{4}$ ebullition}

CH4 ebullition in each littoral embayment site was captured using two inverted funnels (Strayer and Tiedje 1978; Del Sontro et al. 2010; Mulholland et al. 2010; IHA 2010). Inverted funnels were constructed of vinyl material with minimal seams and no openings along their interior collection surface. These funnels channeled ebullated CH4 bubbles from a $0.79 \mathrm{~m}^{2}$ opening at a depth of $2 \mathrm{~m}$ into a sealed syringe at their terminus. Inverted funnels were deployed for approximately 24 hours at each location, using four construction bricks as an anchor. Upon 
retrieval, the funnels were carefully lifted to just below the water's surface, and the captured gas withdrawn with another syringe (sometimes multiple syringes were filled from the gas reservoir of one funnel; in this case the sample from each syringe was collected as an individual sample). $\mathrm{CH}_{4}$ headspace samples were preserved along with surface flux and degassing flux samples until $\mathrm{GC}$ analysis. Flux $\left(F_{E}\right)$ in $\mathrm{mg} \mathrm{CH}_{4} \mathrm{~m}^{-2} \mathrm{~d}^{-1}$ was calculated using the following equation:

$$
F_{E}=\left[\mathrm{CH}_{4}\right] \times \mathrm{Vol} / T_{d} \times A_{f}
$$

Where $F_{E}$ is ebullition of $\mathrm{CH}_{4},\left[\mathrm{CH}_{4}\right]$ is the $\mathrm{CH}_{4}$ concentration (or the mean concentration if multiple samples were collected from one 24 hour funnel deployment), $\mathrm{Vol}$ is the volume of gas sampled, $T_{d}$ is the number of days the funnel was deployed, and $A_{f}$ is the cross sectional area of the funnel.

\subsubsection{Hyporheic Flux of $\mathrm{CO}_{2}$ and $\mathrm{CH}_{4}$}

A Ponar dredge was used to collect substrate samples from three random locations at each embayment site in March 2012. Each of these three samples was analyzed for sediment grainsize distribution, organic, and inorganic $\mathrm{C}$ content. Previous studies on the Snake River utilizing a Ponar dredge have revealed little to no significant seasonal differences among results (Arntzen et al. 2012). Substrate samples were dried inside a vented oven at $105^{\circ} \mathrm{C}$ for 24 hours. The dried samples were then be sieved into 1-phi size classes from $64 \mathrm{~mm}$ (-6 phi) to $0.062 \mathrm{~mm}$ (4 phi). For each sample, the weight of the substrate in each size class was taken, yielding a percent-by-weight value for each size class. All laboratory sample handling and quality assurance and quality control followed the guidelines of Guy (1969). The inorganic and organic carbon content of fine sediments less than $2 \mathrm{~mm}$ was determined using the loss on ignition method (LOI; Heiri et al. 2001; Arntzen et al. 2012). A 20 g sample of the less than $2 \mathrm{~mm}$ portion was taken from each sample. If less than 20 grams of fine sediment was available, the entirety of the less than $2 \mathrm{~mm}$ portion was taken for LOI. Samples were fired at $550^{\circ} \mathrm{C}$ for four hours in a muffle furnace. The difference between their masses prior to ignition and masses following ignition was calculated as percent organic carbon.

Concentrations of $\mathrm{CO}_{2}$ and $\mathrm{CH}_{4}$ present within the upper strata of benthic sediments and the hyporheic zone, where methanogenesis and gas ebullition originates, was determined by installing two mini piezometers at sites where ebullition funnels were deployed. These were installed at a subsurface depth of approximately $10 \mathrm{~cm}$, where $\mathrm{CH}_{4}$ concentrations have been shown to peak in pore water, and a surface water depth of approximately $4 \mathrm{~m}$ (Furrer and Wehrli 1996; Schindler and Krabbenhoft 1998). $\mathrm{CO}_{2}$ and $\mathrm{CH}_{4}$ headspace samples were taken from mini piezometers following the funnels' retrieval. Installation and sampling of mini piezometers, then the funnels, was timed to avoid releasing and measuring greater quantities of $\mathrm{CO}_{2}$ and $\mathrm{CH}_{4}$ in the ebullition funnels from a disturbed benthos. To retrieve a headspace sample, water was withdrawn from the mini piezometers' $0.64 \mathrm{~cm}$ diameter polyethylene tubing with a syringe 
while a peristaltic pump was in operation (Arntzen 2001). Before sampling, tubing was purged with up to three volumes of water (Arntzen 2001). The tubing was moored at the water's surface with a buoy for subsequent sampling. $\mathrm{CO}_{2}$ and $\mathrm{CH}_{4}$ headspace samples were also taken with a

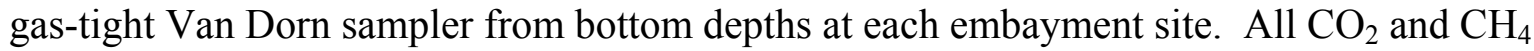
headspace samples were then stored along with surface flux, degassing flux, and ebullition flux headspace samples until $\mathrm{GC}$ analysis. Flux of $\mathrm{CO}_{2}$ and $\mathrm{CH}_{4}$ was calculated using pore-water and bottom depth headspace sample concentrations (gathered by gas tight Van Dorn, as described previously), as well as porosity ( $\varnothing)$ and tortuosity $(\theta)$ estimated from sediment grainsize data (Berner 1980; Huttunen et al. 2006) using the following derivation of Fick's First Law of Diffusion:

$$
F_{\text {Porewater }}=-\varnothing\left(D_{0} \times \theta^{-2}\right) d C / d z
$$

Where $F_{\text {Porewater }}$ is the diffusive flux of $\mathrm{CO}_{2}$ or $\mathrm{CH}_{4}$ at the sediment-water interface, $D_{0}$ is the diffusion coefficient for $\mathrm{CO}_{2}$, or $\mathrm{CH}_{4}, d \mathrm{C} / d z$ is the concentration gradient measured between the pore-water headspace sample at $10 \mathrm{~cm}$ and Van Dorn headspace sample at the sediment-water interface, $\varnothing$ is sediment porosity, and $\theta$ is sediment tortuosity. Temperature dependent diffusion coefficients were obtained from Broecker and Peng (1974). During winter sampling (FebMarch) surface water temperatures in littoral embayments ranged from approximately $4-7^{\circ} \mathrm{C}$, and diffusion coefficients for $\mathrm{CO}_{2}$ and $\mathrm{CH}_{4}$ were selected assuming an average water temperature of $5^{\circ} \mathrm{C}$.

Table 1. Porosity values for various substrates determined using grainsize distributions found in greatest proportion at each littoral embayment, together with the relationship presented by Stephens et al. (1998).

\begin{tabular}{|c|l|c|}
\hline Location & Substrate Type $\left(\mathrm{D}_{50}\right)$ & Porosity \\
\hline Han-C1 & Fine Sand & 0.42 \\
\hline Han-C2 & Medium Sand & 0.40 \\
\hline LMN-C1 & Fine Silt & 0.50 \\
\hline LMN-C2 & Course Silt & 0.45 \\
\hline PRD-C1 & Medium Sand & 0.40 \\
\hline PRD-C2 & Coarse Silt & 0.45 \\
\hline
\end{tabular}

Diffusion coefficients used for $\mathrm{CO}_{2}$ and $\mathrm{CH}_{4}\left(\right.$ in $10^{-5} \mathrm{~cm}^{2} / \mathrm{s}$ ) were 1.08 and 1.14 , respectively. During summer sampling (September), surface water temperatures within embayments ranged from approximately $18^{\circ} \mathrm{C}$ to $21^{\circ} \mathrm{C}$, and diffusion coefficients were selected assuming an average water temperature of $20^{\circ} \mathrm{C}$. For summer samples, diffusion coefficients used for $\mathrm{CO}_{2}$ and $\mathrm{CH}_{4}$ (in $10^{-5} \mathrm{~cm}^{2} / \mathrm{s}$ ) were 1.64 and 1.75 , respectively. Sediment porosity was estimated using the $D_{50}$ sorting index from our sediment grainsize distribution (the grainsize that $50 \%$ of the sample was finer than). The $D_{50}$ value was related to porosity using a relationship published by Stephens et 
al. (1998). Sediment tortuosity was then estimated directly from the resulting sediment porosity as outlined in Sweerts (1991):

$$
\theta^{2}=0.73 \varnothing+2.17
$$

\subsubsection{Laboratory analysis}

Methane and carbon dioxide concentrations were analyzed by gas chromatography (GC). The gas chromatograph was an SRI Instruments model 8610C equipped with a flame ionization detector (FID) and a methanizer accessory to enable measurement of $\mathrm{CO}_{2}$. A 1-mL gas sample loop was used to inject samples onto the packed separation columns, which consisted of $2 \mathrm{~m}$ Haysep-Dand $1 \mathrm{~m}$ Shincarbon joined with a $30 \mathrm{~cm}$ length of $1 / 8$ " OD copper tubing.. The $\mathrm{N}_{2}$ carrier gas pressure was set at $20 \mathrm{psi}$, and the column temperature was $100^{\circ} \mathrm{C}$. A set of four standards ranging in concentration from 9.93 to $245 \mathrm{ppm}$ for $\mathrm{CH}_{4}$ and 205.5 to $5018 \mathrm{ppm}$ for $\mathrm{CO}_{2}$ was used for calibration. Blanks and check standards were run regularly between samples; standard recoveries ranged from $56 \%$ to $180 \%$ for $\mathrm{CH}_{4}($ mean $=101 \%$ ) and $96 \%$ to $101 \%$ for $\mathrm{CO}_{2}($ mean $=99 \%)$. 


\subsection{Results}

\subsection{Surface flux of $\mathrm{CH}_{4}$ and $\mathrm{CO}_{2}$}

Mean surface flux of $\mathrm{CH}_{4}$ (determined using thin boundary layer calculations) was determined for the September sampling effort only, with small and slightly positive mean (standard deviation, SD) fluxes ranging up to $0.08 \mathrm{mg} \mathrm{CH}_{4} \mathrm{~m}^{-2} \mathrm{~d}^{-1}\left(0.08 \mathrm{mg} \mathrm{CH}_{4} \mathrm{~m}^{-2} \mathrm{~d}^{-1}\right)$ in the Hanford Reach of the Columbia River (Figure 2).
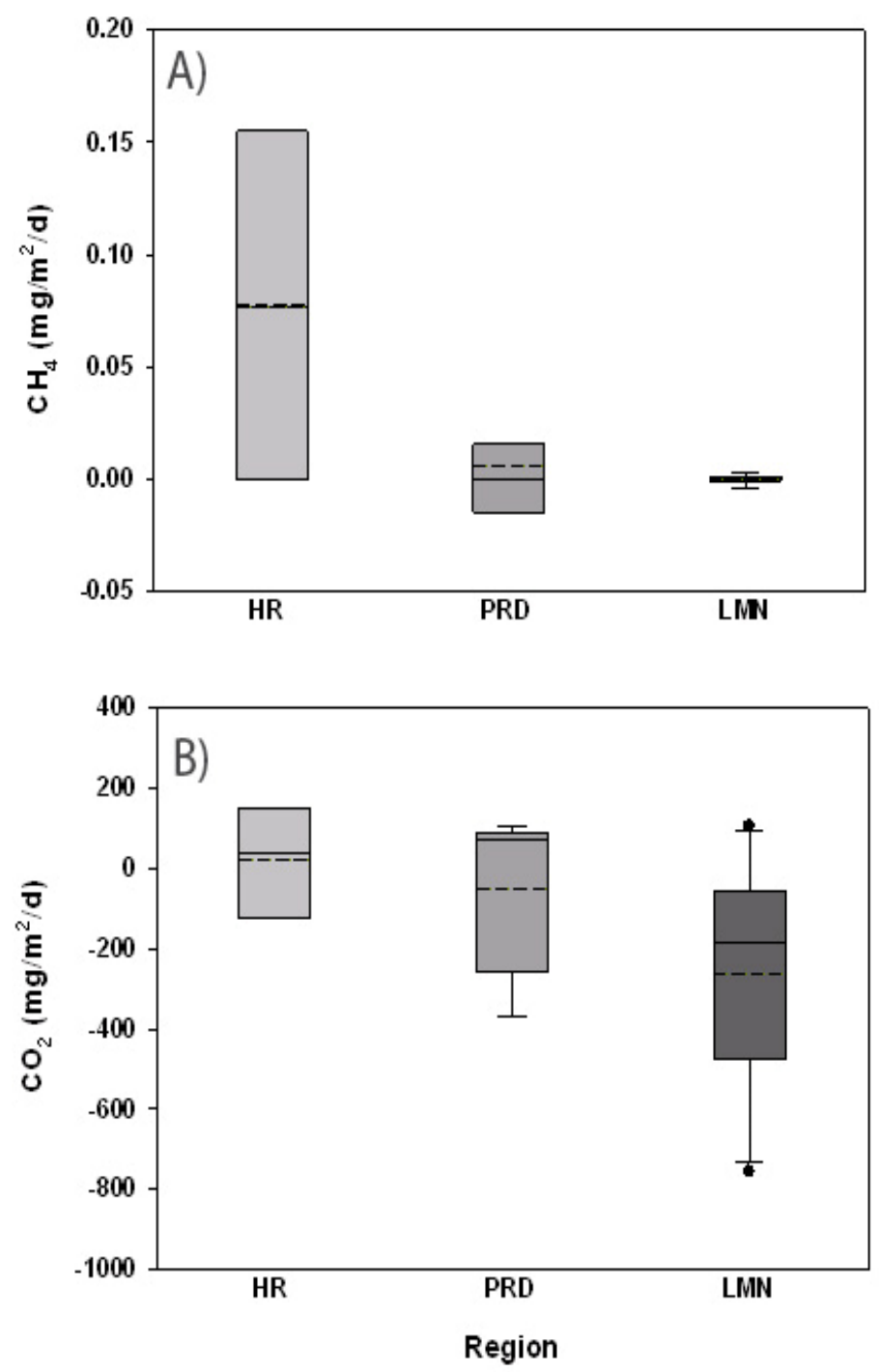

Figure 2. Surface water flux for A) $\mathrm{CH}_{4}$ and $\mathrm{B}$ ) $\mathrm{CO}_{2}$ across sampling environments in the Hanford Reach (HR), Priest Rapids hydroelectric dam complex (PRD), and Lower Monumental hydroelectric dam complex (LMN). Solid horizontal lines within each box represent median flux, dashed lines within each box represent mean flux, ends of boxes represent the $25^{\text {th }}$ and $75^{\text {th }}$ percentiles and black dots represent outliers. 
$\mathrm{CH}_{4}$ efflux within the Priest Rapids and Lower Monumental Dam complexes occurred but was very minimal, with small positive fluxes within the Priest Rapids complex and very small negative flux within the Lower Monumental Dam complex (Figure 2). The free flowing Hanford Reach was a source of $\mathrm{CO}_{2}$, with a mean (SD) flux of $21.7 \mathrm{mg} \mathrm{m}^{-2} \mathrm{~d}^{-1}\left(146.3 \mathrm{mg} \mathrm{m}^{-2} \mathrm{~d}^{-1}\right)$. The Lower Monumental Dam complex was a sink for $\mathrm{CO}_{2}$, with a mean (SD) flux $-262 \mathrm{mg} \mathrm{m}^{-2} \mathrm{~d}^{-1}$ $\left(265 \mathrm{mg} \mathrm{m}^{-2} \mathrm{~d}^{-1}\right)$. The Priest Rapids Dam complex was also a sink for CO2 with mean (SD) flux of $-48.5 \mathrm{mg} \mathrm{m}^{-2} \mathrm{~d}^{-1}\left(190.8 \mathrm{mg} \mathrm{m}^{-2} \mathrm{~d}^{-1}\right)$.

\subsection{Degassing of $\mathrm{CH}_{4}$ and $\mathrm{CO}_{2}$ at hydroelectric dam projects}

Relative atmospheric contributions of $\mathrm{CH}_{4}$ and $\mathrm{CO}_{2}$ were evaluated by measuring gas concentrations in the forebay and the tailrace of hydroelectric dam projects as water passed through the turbines and spillway during March and September, 2012 (Figure 3). Results were highly variable within each hydroelectric dam project sampled. Overall, during March, tailrace concentrations of $\mathrm{CH}_{4}$ were lower than forebay concentrations, meaning the system was a source for $\mathrm{CH}_{4}$ with a mean degassing flux of $3.1 \times 10^{-6} \mathrm{tCH}_{4} \mathrm{~d}^{-1}$ (Figure 3). During September, the system was a sink for $\mathrm{CH}_{4}$ with a mean (SD) degassing flux of $-5.6 \times 10^{-4} \mathrm{t} \mathrm{CH}_{4} \mathrm{~d}^{-1}\left(9.8 \times 10^{-4} \mathrm{t}\right.$ $\mathrm{CH}_{4} \mathrm{~d}^{-1}$ ) (Figure 3). During March, the system was a sink for $\mathrm{CO}_{2}$ with a mean (SD) degassing flux of $-117 \mathrm{t} \mathrm{CO}_{2} \mathrm{~d}^{-1}\left(200 \mathrm{t} \mathrm{CO}_{2} \mathrm{~d}^{-1}\right)$. During September degassing was a source of $\mathrm{CO}_{2}$, with a mean (SD) degassing flux of $4.5 \mathrm{t} \mathrm{CO}_{2} \mathrm{~d}^{-1}\left(66 \mathrm{t} \mathrm{CO}_{2} \mathrm{~d}^{-1}\right)$ (Figure 3). 

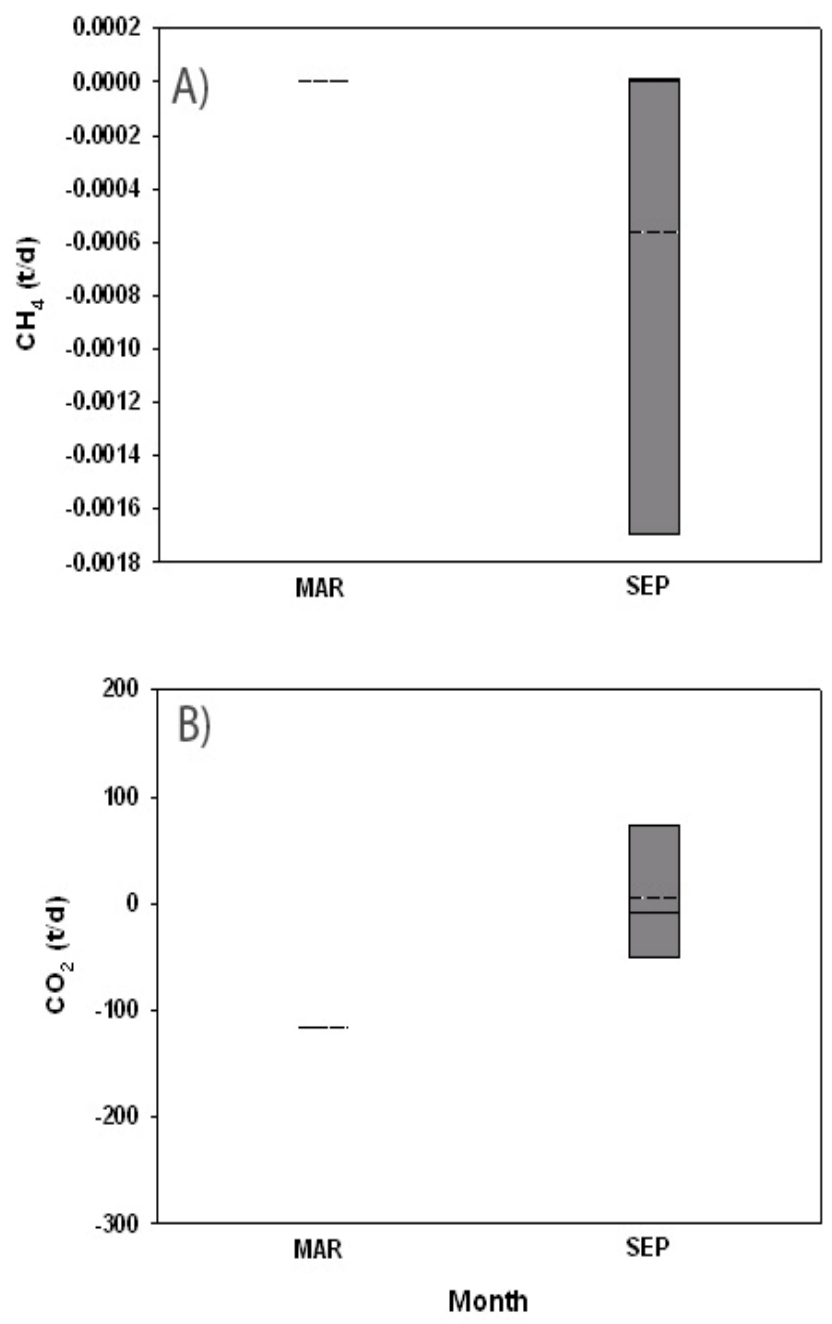

Figure 3. Degassing flux values for $\mathrm{A}) \mathrm{CH}_{4}\left(\mathrm{td}^{-1}\right)$ and $\left.\mathrm{B}\right) \mathrm{CO}_{2}\left(\mathrm{td}^{-1}\right)$ across hydroelectric dam projects in March 2012 and September 2012. Solid horizontal lines within each box represent median flux, dashed horizontal lines represent mean flux, and ends of boxes represent the $25^{\text {th }}$ and $75^{\text {th }}$ percentile.

\subsection{Ebullition of $\mathrm{CH}_{4}$ and $\mathrm{CO}_{2}$ in littoral embayments}

Methane and carbon dioxide ebullition were measured from littoral embayments, or coves, by capturing bubbles ascending through the water column with inverted funnel samplers during March and September, 2012. Mean concentrations of $\mathrm{CH}_{4}$ and $\mathrm{CO}_{2}$ exceeded 7,000 $\mathrm{mgL}^{-1}$ and $4,000 \mathrm{mgL}^{-1}$, respectively, during September and were approximately an order of magnitude lower during March (Figure 4). 

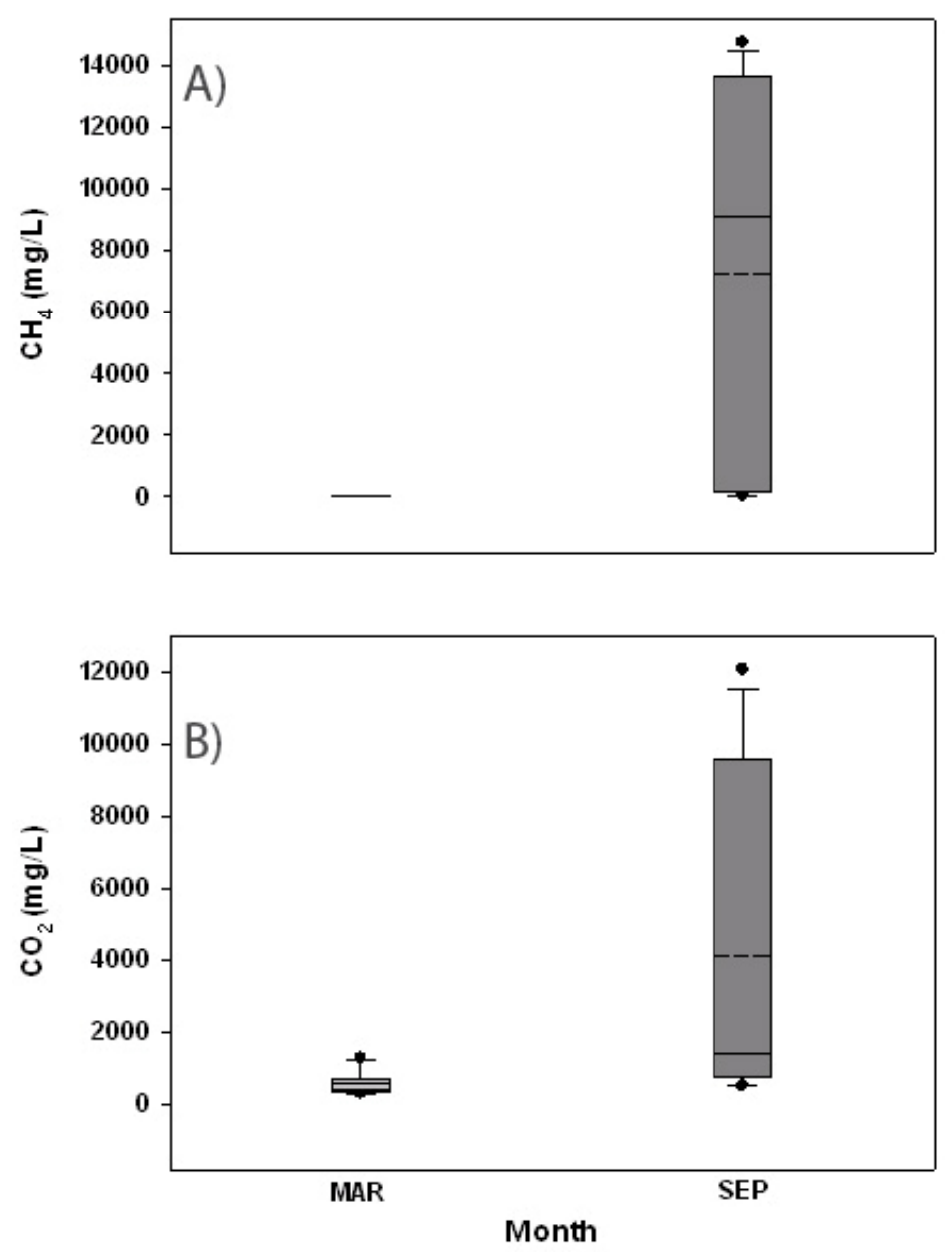

Figure 4. Gas concentration values $\left(\mathrm{mgL}^{-1}\right)$ for $\left.\mathrm{A}\right) \mathrm{CH}_{4}$ and $\left.\mathrm{B}\right) \mathrm{CO}_{2}$ gas samples collected in funnels from all littoral embayments during September 2012. Solid horizontal lines within each box represent median concentration, dashed lines within each box represent mean concentration, ends of boxes represent the $25^{\text {th }}$ and $75^{\text {th }}$ percentiles and black dots represent outliers.

This result is to be expected, with higher $\mathrm{CH}_{4}$ flux expected with increased summer temperatures (Del Sontro et al. 2010). $\mathrm{CH}_{4}$ eflux due to ebullition exceeded that of $\mathrm{CO}_{2}$. This result may be explained by the comparatively low solubility of $\mathrm{CH}_{4}$ in water at standard temperature and pressure (Wilhelm et al. 1977). Gas efflux due to ebullition was greater in embayments located within reservoirs than in embayments within the free flowing Hanford Reach-this was true for both $\mathrm{CH}_{4}$ and $\mathrm{CO}_{2}$ (Figure 5). 

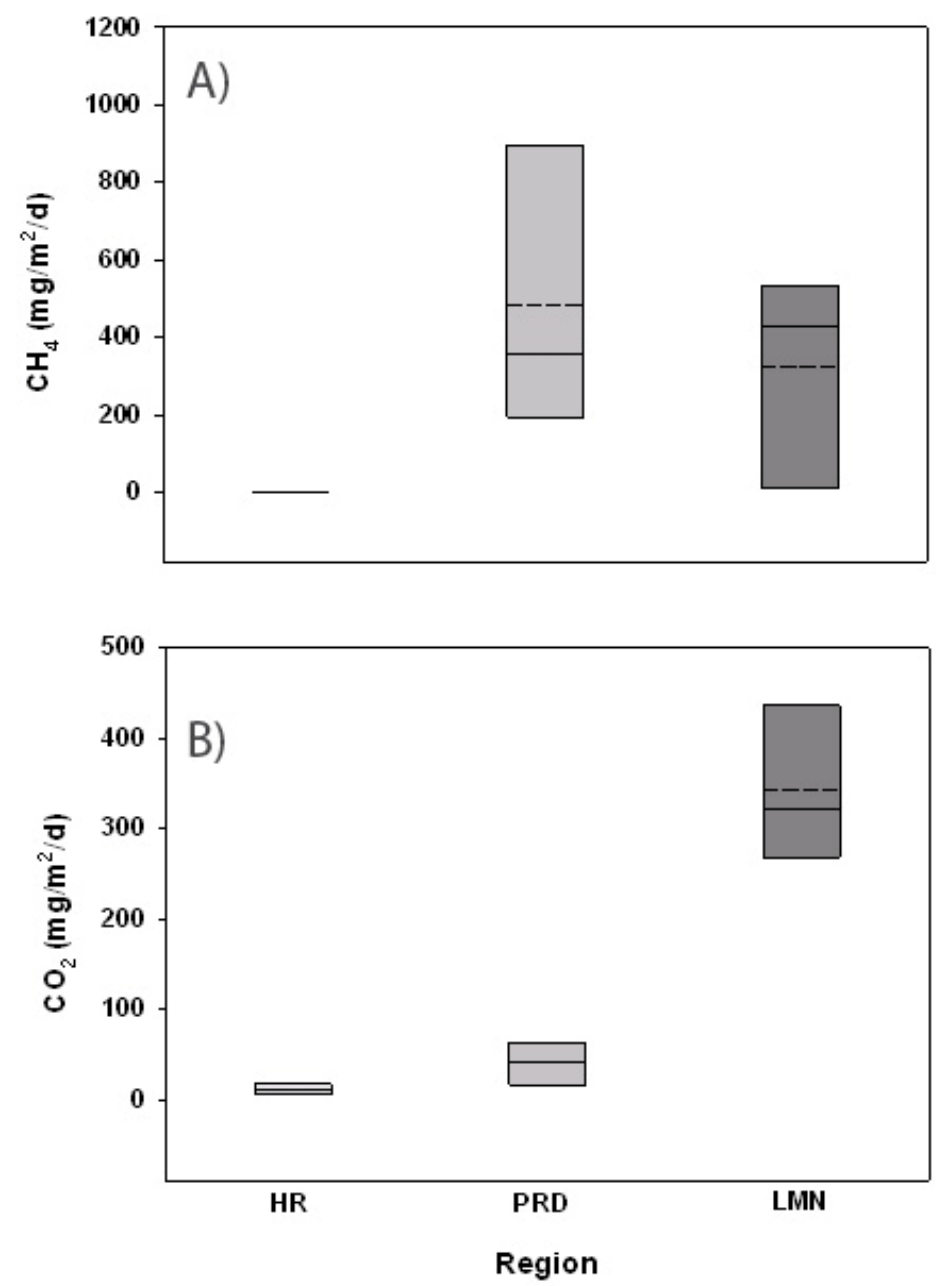

Figure 5. Flux values ( $\mathrm{mg} \mathrm{m}^{-2} \mathrm{~d}^{-1}$ ) for $\left.\mathrm{A}\right) \mathrm{CH}_{4}$ and $\left.\mathrm{B}\right) \mathrm{CO}_{2}$ gas samples collected using inverted funnel samplers with littoral cove sampling environments in the Hanford Reach (HR), Priest Rapids hydroelectric dam complex (PRD), and Lower Monumental hydroelectric dam complex (LMN) during September 2012. Solid horizontal lines within each box represent median flux, dashed lines within each box represent mean flux, ends of boxes represent the $25^{\text {th }}$ and $75^{\text {th }}$ percentiles and black dots represent outliers.

Estimated $\mathrm{CH}_{4}$ emissions due to ebullition varied widely across sampling locations. Within Lower Monumental Dam reservoir embayments, $\mathrm{CH}_{4}$ flux ranged from approximately 10.5 to $533 \mathrm{mg} \mathrm{CH}_{4} \mathrm{~m}^{-2} \mathrm{~d}^{-1}$, with a mean (SD) flux of $324 \mathrm{mg} \mathrm{CH}_{4} \mathrm{~m}^{-2} \mathrm{~d}^{-1}\left(276 \mathrm{mg} \mathrm{CH}_{4} \mathrm{~m}^{-2} \mathrm{~d}^{-1}\right)$ (Figure 5). For embayments within the Priest Rapids Dam reservoir, $\mathrm{CH}_{4}$ flux ranged from approximately 176 to $1039 \mathrm{mg} \mathrm{CH}_{4} \mathrm{~m}^{-2} \mathrm{~d}^{-1}$, with a mean (SD) flux of $482 \mathrm{mg} \mathrm{CH}_{4} \mathrm{~m}^{-2} \mathrm{~d}^{-1}$ (391 mg $\left.\mathrm{CH}_{4} \mathrm{~m}^{-2} \mathrm{~d}^{-1}\right)$. Maximum $\mathrm{CH}_{4}$ flux from Hanford Reach coves was less than $4 \mathrm{mg} \mathrm{CH}_{4} \mathrm{~m}^{-2} \mathrm{~d}^{-1}$. Mean (SD) carbon dioxide ebullition flux ranged from approximately $10.9 \mathrm{mg} \mathrm{CO}_{2} \mathrm{~m}^{-2} \mathrm{~d}^{-1}(5.8$ $\left.\mathrm{mg} \mathrm{CO} 2 \mathrm{~m}^{-2} \mathrm{~d}^{-1}\right)$ from Hanford Reach coves to approximately $342 \mathrm{mg} \mathrm{CO}_{2} \mathrm{~m}^{-2} \mathrm{~d}^{-1}\left(85.9 \mathrm{mg} \mathrm{CO}_{2}\right.$ $\mathrm{m}^{-2} \mathrm{~d}^{-1}$ ) from Lower Monumental Dam reservoir coves (Figure 5). 


\subsection{Hyporheic Flux of $\mathrm{CH}_{4}$ and $\mathrm{CO}_{2}$}

$\mathrm{CH}_{4}$ and $\mathrm{CO}_{2}$ flux within sediment pore-water in littoral embayments was sampled from piezometers installed within the hyporheic zone during March and September, 2012. $\mathrm{CH}_{4}$ efflux rates were higher during September, with mean (SD) flux averaging $4.2 \mathrm{mg} \mathrm{m}^{-2} \mathrm{~d}^{-1}\left(4.4 \mathrm{mg} \mathrm{m}^{-2} \mathrm{~d}^{-}\right.$ ${ }^{1}$ ) during March and $8.1 \mathrm{mg} \mathrm{m}^{-2} \mathrm{~d}^{-1}\left(10.5 \mathrm{mg} \mathrm{m}^{-2} \mathrm{~d}^{-1}\right)$ during September (Figure 6).
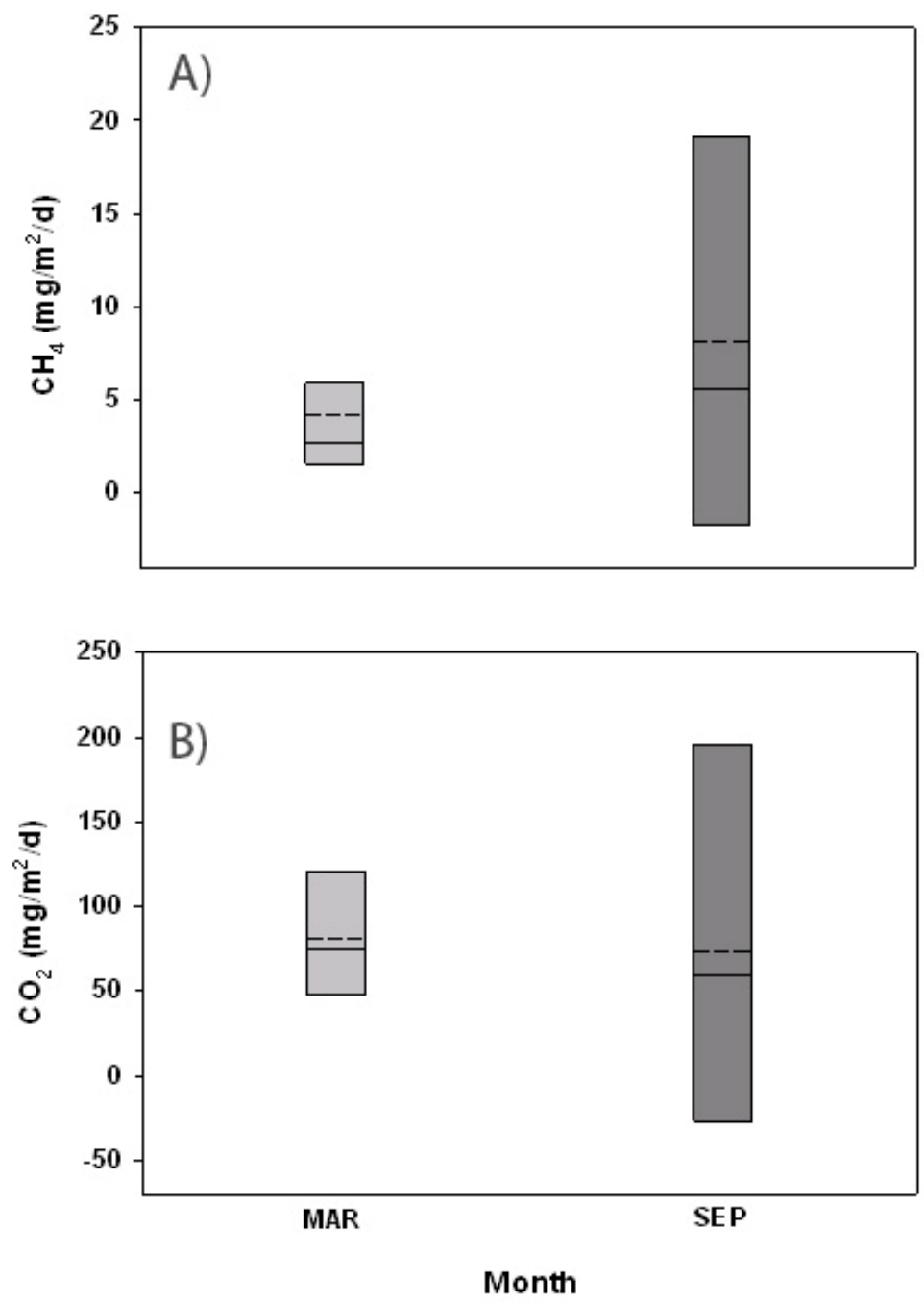

Figure 6. Porewater flux of A) $\mathrm{CH} 4\left(\mathrm{mg} \mathrm{m}^{-2} \mathrm{~d}^{-1}\right)$ and B) $\mathrm{CO}_{2}\left(\mathrm{mg} \mathrm{m}^{-2} \mathrm{~d}^{-1}\right)$ in littoral bays aross all study regions during March 2012 and September 2012. Solid horizontal lines within each box represent median flux, dashed horizontal lines within each box represent mean flux, and ends of boxes represent the $25^{\text {th }}$ and $75^{\text {th }}$ percentiles.

For $\mathrm{CO}_{2}$ flux, there was little difference between March and September, with mean (SD) flux rates of $\mathrm{CO}_{2}$ averaging $80.6 \mathrm{mg} \mathrm{m}^{-2} \mathrm{~d}^{-1}\left(35.0 \mathrm{mg} \mathrm{m}^{-2} \mathrm{~d}^{-1}\right)$ during March and $73.5 \mathrm{mg} \mathrm{m}^{-2} \mathrm{~d}^{-1}(109.7$ $\mathrm{mg} \mathrm{m}^{-2} \mathrm{~d}^{-1}$ ) during September (Figure 6). 

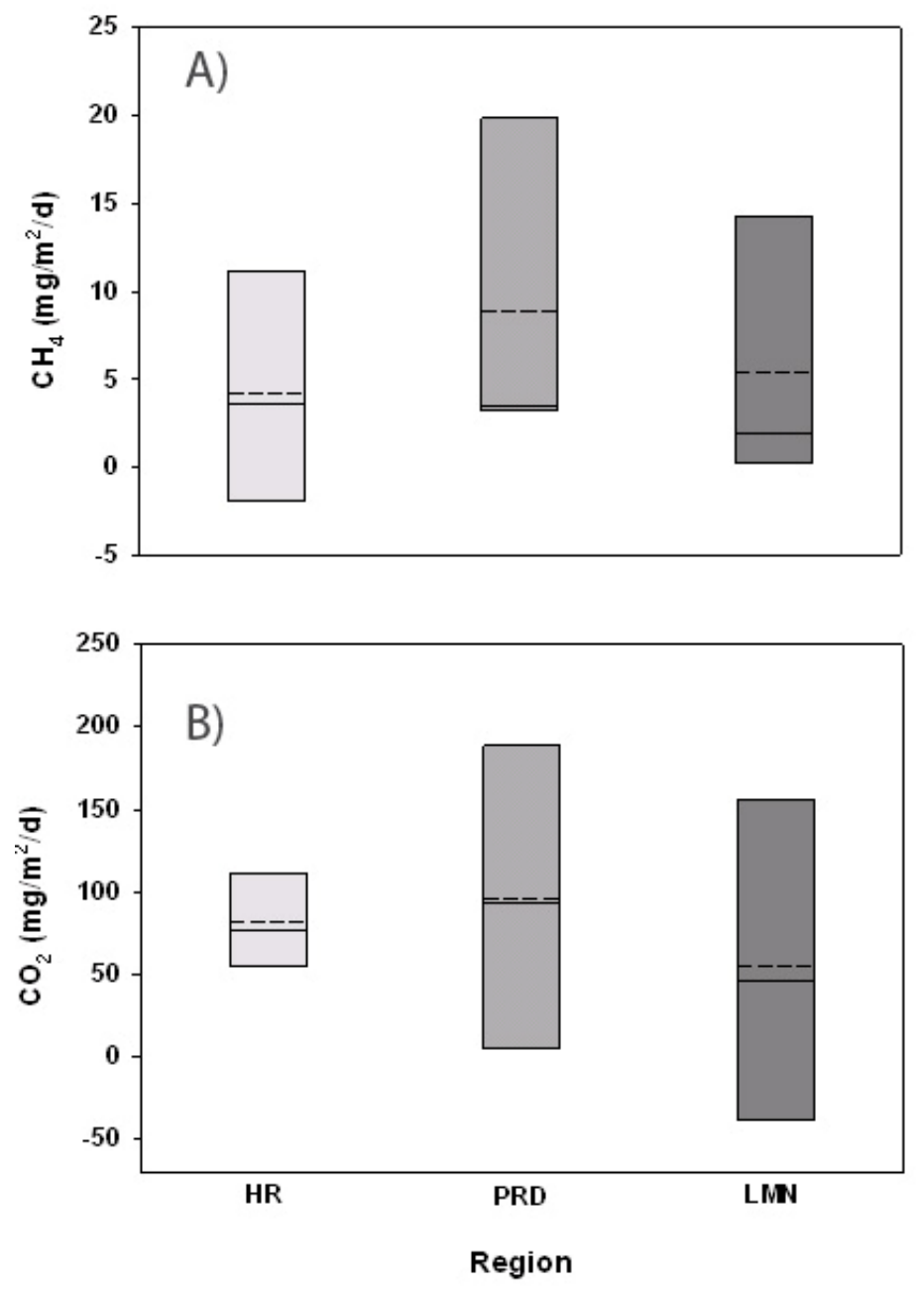

Figure 7. Porewater flux for A) $\mathrm{CH}_{4}\left(\mathrm{mg} \mathrm{m}^{-2} \mathrm{~d}^{-1}\right)$ and B) $\mathrm{CO}_{2}\left(\mathrm{mg} \mathrm{m}^{-2} \mathrm{~d}^{-1}\right)$ in littoral bays within the Hanford Reach (HR), Priest Rapids hydroelectric dam complex (PRD), and Lower Monumental hydroelectric dam complex (LMN) in March and September 2012. Solid horizontal lines within each box represent median flux, dashed lines represent mean flux, and ends of boxes represent the $25^{\text {th }}$ and $75^{\text {th }}$ percentiles.

Similar to results for $\mathrm{CH}_{4}$ ebullition, $\mathrm{CH}_{4}$ flux from sediment pore-water was higher in reservoirs than in the free flowing Hanford Reach, although the differences were small (Figure 7). Maximum $\mathrm{CH}_{4}$ flux from sediment pore-water was $19.8 \mathrm{mg} \mathrm{m}^{-2} \mathrm{~d}^{-1}$ from a littoral bay within the Priest Rapids Dam reservoir, where $\mathrm{CH}_{4}$ ebullition was also the greatest (Figure 7). $\mathrm{CO}_{2}$ from pore-water flux was greater than the $\mathrm{CO}_{2}$ flux due to ebullition within Hanford Reach and Priest Rapids littoral bays; however this was untrue for the Lower Monumental Dam reservoir, where $\mathrm{CO}_{2}$ flux rates due to ebullition were substantially higher than those estimated for porewater flux (Figure 7). We found that dissolved $\mathrm{CH}_{4}$ found in benthic sediments and from the overlying surface water were positively correlated with higher levels of DOC (Figure 8). While this relationship was significant $(\mathrm{P}<0.001)$, it was heavily reliant on only two sediment porewater samples and the data used for the comparison were not distributed normally. 


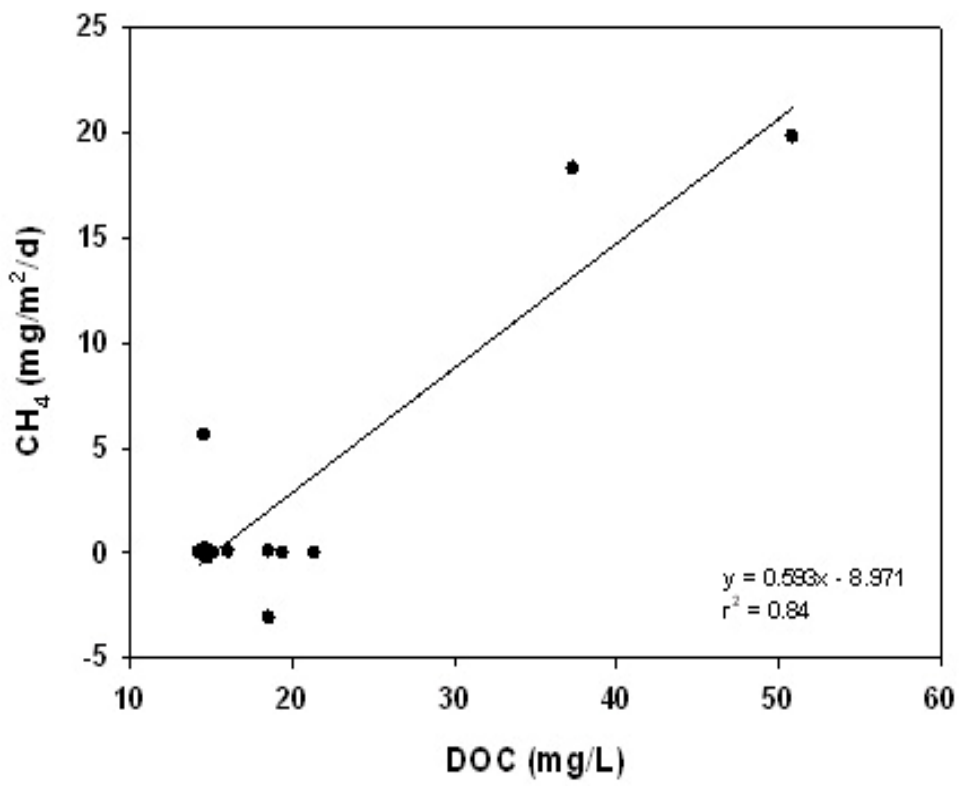

Figure 8. DOC versus $\mathrm{CH}_{4}$ (porewater flux and surface flux combined) for all three regions during September 2012. 


\subsection{Discussion}

The surface fluxes of methane we report here are small compared to those observed by others in similar temperate reservoirs. Delsontro et al. (2010) found that surface fluxes of methane ranged from $1.5 \mathrm{mg} \mathrm{CH}_{4} \mathrm{~m}^{-2} \mathrm{~d}^{-1}$ to $12.0 \mathrm{mg} \mathrm{CH}_{4} \mathrm{~m}^{-2} \mathrm{~d}^{-1}$ from a run-of-river reservoir on the Aare River, Switzerland. Like the run-of-river reservoirs we studied, this reservoir was characterized by oxic conditions and similar temperature regimes to those we studied, with extremes ranging from approximately $5^{\circ} \mathrm{C}$ in winter to approximately $17^{\circ} \mathrm{C}$ during summer (Delsontro et al. 2010). Soumis et al. (2004) reported a range of $\mathrm{CH}_{4}$ surface fluxes between 3.2 and $9.0 \mathrm{mg} \mathrm{CH}_{4} \mathrm{~m}^{-2} \mathrm{~d}^{-1}$ in another September study of different reservoirs - Lakes Wallula and F.D. Roosevelt - on the Columbia River, and St. Louis et al. (2000) found a range between 3.0 and $11.0 \mathrm{mg} \mathrm{CH}_{4} \mathrm{~m}^{-2} \mathrm{~d}^{-1}$ in temperate Wisconsin. Concomitant with our study, Mulholland et al. (2010) measured diffusive emissions of typically less than $10 \mathrm{mg} \mathrm{CH}_{4} \mathrm{~m}^{-2} \mathrm{~d}^{-1}$ in temperate Tennessee, with some higher surface effluxes in littoral embayment areas. In their review paper synthesizing results from 85 published reservoir studies worldwide, including those in the tropical and boreal zones, where flux is highest, Barros et al. (2011) estimates that reservoirs emit 5.80E+12 $\mathrm{g} \mathrm{CH}_{4} \mathrm{y}^{-1}$, accounting for $7 \%$ of annual lacustrine emissions. Of these, temperate reservoirs are assumed to emit 1.00E $+11 \mathrm{~g} \mathrm{CH}_{4} \mathrm{y}^{-1}$ (Barros et al. 2011). According to our mainstem results, extrapolated annual emissions of $\mathrm{CH}_{4}$ from water surface diffusion is $350 \mathrm{~g} \mathrm{CH}_{4} \mathrm{y}^{-1}$ from Priest Rapids Dam complex, and $-0.5 \mathrm{~g} \mathrm{CH}_{4} \mathrm{y}^{-1}$ from Lower Monumental Dam complex. Surface flux is generally measured using a floating dome sampler, and we estimated surface flux exclusively using thin boundary layer calculations, a difference that may have contributed to our comparatively low flux estimates (Duchemin et al. 1999).

The reservoirs we sampled were sinks for $\mathrm{CO}_{2}$, with mean flux rates ranging from $-48.5 \mathrm{mg}$ $\mathrm{m}^{-2} \mathrm{~d}^{-1}$ to $-262 \mathrm{mg} \mathrm{m}^{-2} \mathrm{~d}^{-1}$. Previous research within different reservoirs in the same xeric, temperate region of the United States found varying results, with $\mathrm{CO}_{2}$ surface flux emissions ranging up to $1,247 \mathrm{mg} \mathrm{m}^{-2} \mathrm{~d}^{-1}$ from Shasta Reservoir, and several reservoirs acting as sinks for $\mathrm{CO}_{2}$, with fluxes ranging from -349 to $-1195 \mathrm{mg} \mathrm{m}^{-2} \mathrm{~d}^{-1}$ (Soumis et al. 2004). Given this range in values, our $\mathrm{CO}_{2}$ surface flux results are thus comparable to previous studies in similar locations.

Previous research in temperate western reservoirs of the U.S. showed that as water passed through turbines, GHG was emitted into the atmosphere (Soumis et al. 2004). Our results differ from these findings. Overall, the tailrace environment we sampled consistently acts as a sink for $\mathrm{CO}_{2}$. Results may differ because we directly measured gas concentrations within tailrace environments. Soumis et al. (2004) measured gas concentrations in the forebay and estimated them for tailrace environments, reporting a $\mathrm{CO}_{2}$ degassing (efflux) of $324 \pm 95,16 \pm 4$, and 224 $\pm 56 \mathrm{t} \mathrm{d}^{-1}$ in the tailraces of Grand Coulee, Dworshak, and McNary Dams, respectively. Two of these hydroelectric dam complexes, Grand Coulee and McNary, are also located on the Columbia. Soumis et al. (2004) assumed that downstream, tailrace water concentrations were at equilibrium with mean ambient atmospheric concentrations of $\sim 375 \mathrm{ppm} \mathrm{CO} 2$. However, as 
Roehm and Tremblay (2006) highlight, this leads to "gross overestimation" because dissolved $\mathrm{CO}_{2}$ is often supersaturated immediately downstream of hydroelectric dams. This is supportive of both our magnitude of results and our findings of $\mathrm{CO}_{2}$ influx, due to $\mathrm{CO}_{2}$ supersaturation in the tailrace relative to the forebay. Examining two of the Le Grande reservoirs in the boreal zone, Roehm and Tremblay (2006) reported $\mathrm{CO}_{2}$ efflux based on turbine discharge of 5 to 45 and 5 to $25 \mathrm{t} \mathrm{d}^{-1}$, but note the seasonal variability often observed with degassing flux. Other studies that have quantified such fluxes have generally been conducted outside of the temperate zone, in the tropics (Galy-Lacaux et al. 1997; Guerin et al. 2006; Del Sontro et al. 2011). We measured very minimal influx of $\mathrm{CH}_{4}$ due to degassing, with an overall net flux of $-4.2 \times 10^{-4} \mathrm{t} \mathrm{CH}_{4} \mathrm{~d}^{-1}$. Soumis et al. (2004) also found low emissions of $\mathrm{CH}_{4}$ via this pathway, with values ranging from 0.003 to $0.815 \mathrm{t} \mathrm{CH}_{4} \mathrm{~d}^{-1}$.

Based on the relatively cool, oxygenated conditions in the reservoirs that were sampled, it was expected that ebullition would represent a relatively minor input to overall $\mathrm{CH}_{4}$ flux within the reservoirs we surveyed. However, the efflux of $\mathrm{CH}_{4}$ from ebullition within littoral embayments was relatively high ( 10.5 to $533 \mathrm{mg} \mathrm{CH}_{4} \mathrm{~m}^{-2} \mathrm{~d}^{-1}$ ). The greatest effluxes were measured in shallow ( $<10 \mathrm{~m}$ deep) littoral embayments where surface water temperature was approximately $20^{\circ} \mathrm{C}$ and dissolved oxygen levels exceeded $6 \mathrm{mgL}^{-1}$. These areas were characterized by low water velocity (near zero), surrounded by land used for agriculture and were likely not nutrient limited, with mean $\mathrm{NO}_{3}{ }^{-}$and $\mathrm{PO}_{4}{ }^{3-}$ concentrations of $1.48 \mathrm{mg} \mathrm{L}^{-1}$ and $0.36 \mathrm{mg} \mathrm{L}^{-1}$, respectively. Additionally, aquatic plants such as Eurasian watermilfoil (Myriophyllum spicatum) are known to thrive in backwater areas of the Columbia and lower Snake Rivers, which may deplete dissolved $\mathrm{CO}_{2}$ during diurnal periods of photosynthesis, provide substrates - including DOC - to respiring microbial communities within littoral sediments, and serve as conduits for dissolved $\mathrm{CH}_{4}$ to surface water (Kelker and Chanton 1997; Wetzel 2001; Seybold and Bennett 2010; Arntzen et al. 2012). $\mathrm{CH}_{4}$ fluxes of a similar magnitude to those we found have recently been identified in littoral zones of other temperate reservoirs. Chen et al. (2009) found methane fluxes in littoral marshes of the Three Gorges Reservoir, China, that were approximately $360 \mathrm{mg} \mathrm{CH}_{4} \mathrm{~m}^{-2} \mathrm{~d}^{-1}$, a value within the range of effluxes we measured. DelSontro et al. (2010) sampled a Swiss, run-of-river reservoir (Lake Wohlen), and found methane ebullition was greatest when water quality conditions were similar to the conditions we measured during September, 2012 (i.e., dissolved oxygen concentration indicated oxic conditions, and temperatures exceeded $17^{\circ} \mathrm{C}$ ). DelSontro et al. (2010) found $\mathrm{CH}_{4}$ ebullition resulting in emissions of approximately $1,000 \mathrm{mg} \mathrm{CH}_{4} \mathrm{~m}^{-2} \mathrm{~d}^{-1}$, or approximately 2 to 3 times the efflux we measured for this study. Our investigation was considered preliminary and not designed in order to estimate reservoir wide greenhouse gas emissions via the ebullition pathway; the intent was to determine whether substantial quantities of $\mathrm{CH}_{4}$ were escaping via ebullition from shallow, littoral embayments within the reservoirs we studied. The sites we studied are not unique, and there exists a substantial quantity of similar habitat within the reservoirs examined. In order to estimate reservoir wide emissions due to ebullition it would be necessary to use available hydrodynamic modeling and GIS tools to estimate the area of the reservoir where conditions are representative of the areas we sampled. It would also be useful to 
deploy inverted funnel samplers in some additional locations to determine how representative sampling results and model projections are.

Methane porewater flux was relatively low compared to mean flux from ebullition, and there was little seasonal variability in mean flux, which ranged from approximately $4 \mathrm{mg}$ to $8 \mathrm{mg} \mathrm{CH}$ $\mathrm{m}^{-2} \mathrm{~d}^{-1}$, respectively. It is difficult to directly compare our pore-water flux rates to flux rates from ebullition because of the heterogeneous nature of the ebullition results. However, our results are consistent with other research in temperature reservoirs that found relatively high $\mathrm{CH}_{4}$ flux due to ebullition compared to diffusive flux from sediment porewater. DelSontro et al (2010) found peak $\mathrm{CH}_{4}$ diffusion from sediments to be approximately $40 \mathrm{mg} \mathrm{CH}_{4} \mathrm{~m}^{-2} \mathrm{~d}^{-1}$, and estimated system wide sediment flux of $\mathrm{CH}_{4}$ to be approximately $15 \mathrm{mg} \mathrm{CH}_{4} \mathrm{~m}^{-2} \mathrm{~d}^{-1}$. DelSontro et al. (2010) also found $\mathrm{CH}_{4}$ flux to be relatively constant seasonally, largely owing to the relationship between $\mathrm{CH}_{4}$ solubility and diffusivity with respect to temperature. As temperature increases to approximately $20^{\circ} \mathrm{C}$ (e.g., during the summer months), $\mathrm{CH}_{4}$ solubility decreases while $\mathrm{CH}_{4}$ diffusivity increases by an appreciable percentage (Delsontro et al. 2010). Working in the large boreal reservoirs Lokka and Porttipahta, Huttenun et al. (2006) measured similar, even lower, $\mathrm{CH}_{4}$ efflux from sediments, ranging from 0.44 to $25 \mathrm{mg} \mathrm{CH}_{4} \mathrm{~m}^{-2} \mathrm{~d}^{-1}$.

Molecular diffusion, biological mixing by organisms, respiration, and fermentation are all important benthic processes that govern concentrations of dissolved organic carbon and gases in bottom waters, including $\mathrm{CO}_{2}, \mathrm{CH}_{4}$, and $\mathrm{O}_{2}$ (Wetzel 2001). We expect that a portion of the DOC present in the hyporheic zone sampled was labile, which means it may be respired to produce $\mathrm{CO}_{2}$ under oxic conditions, or fermented to produce $\mathrm{CH}_{4}$ under anoxic conditions (Morel and Herring 1993; Papadimitriou et al. 2002). In this potentially anoxic porewater environment, $10 \mathrm{~cm}$ below the riverbed surface, DOC may be subject to substantial amounts of fermentation and $\mathrm{CH}_{4}$ production may be elevated as a result.

This study provides information about $\mathrm{CH}_{4}$ and $\mathrm{CO}_{2}$ emissions from various pathways within xeric western United States reservoirs. While our surface flux results indicated that the reservoirs sampled in our study were $\mathrm{CO}_{2}$ sinks, and that $\mathrm{CH}_{4}$ surface effluxes were lower compared to other studies conducted in temperate regions, we found substantive methane emissions due to ebullition and porewater flux of methane in littoral embayments, particularly during the summer. Although high, our ebullition and pore-water flux results were comparable to other recent studies conducted in temperate reservoirs. With increasing hydropower development worldwide, it is important to assess the contribution of GHG emissions from all parts of the hydropower complex, including littoral embayments, when considering the relative contribution of hydropower to global anthropogenic GHG emissions. The results presented here add to data collected on other hydropower complexes in the temperate zone that implicates this mode of power production and water management as a modest source of GHG to the atmospheric sink. 



\subsection{References}

Arntzen, E.V. 2001. In-situ testing and water quality sampling in the hyporheic zone of the Columbia River, Hanford Reach, Washington. Portland State University.

Arntzen, E.V., Geist, D.R., Murray, K.J., Dawley, E.D., Vavrinec, J., and D.E. Schwartz. 2009. Influence of the Hyporheic Zone on Supersaturated Gas Exposure to Incubating Chum Salmon. North American Journal of Fisheries Management 29: 1714-1727.

Arntzen EV, KJ Klett, BL Miller, RP Mueller, RA Harnish, MA Nabelek, DD Dauble, B Ben James, AT Scholz, MC Paluch, D Sontag, and G Lester. 2012. Habitat Quality and Fish Species Composition/Abundance at Selected Shallow-Water Locations in the Lower Snake River Reservoirs, 2010-2011 -- Final Report. PNWD-4325, Battelle--Pacific Northwest Division, Richland, Washington.

Barros, N., J.J. Cole, L.J. Tranvik, Y.T. Prairie, D. Bastviken, V.L.M. Huszar, P. del Giorgio, and F. Roland. 2011. Carbon emission from hydroelectric reservoirs linked to reservoir age and latitude. Nature Geoscience 4(9): 593-596.

Bastviken, D., J.J. Cole, M. Pace, and L. Tranvik. 2004. Methane emissions from lakes: Dependence on lake characteristics, two regional assessments, and a global estimate. Global Biogeochemical Cycles 18: GB4009.

Bednarek, A.T. 2001. Undamming rivers: A review of the ecological impacts of dam removal. Environmental Management 27(6): 803-814.

Bergstrom, I., S. Makela, P. Kankaala, and P. Kortelainen. 2007. Methane efflux from littoral vegetation stands of southern boreal lakes: An upscaled regional estimate. Atmospheric Environment 41: 339-351.

Berner, R.A. 1980. Early diagenesis: A theoretical approach. Princeton University Press, Princeton, N.J.

Broecker, W.S. and T.H. Peng. 1974. Gas exchange rates between air and sea. Tellus 26: 2135 .

Butman, D., P.A. Raymond, K. Butler, Aiken, G. 2012. Relationships between ${ }^{14} \mathrm{C}$ and the molecular quality of dissolved organic carbon in rivers draining to the coast from the conterminous United States. Global Biogeochemical Cycles 26(4): 0886-6236.

Chen, H., Y. Wu, X. Yuan, Y. Gao, N. Wu, and D. Zhu. 2009. Methane emissions from newly created marshes in the drawdown area of the Three Gorges Reservoir. Journal of Geophysical Research 114: D18301.

Cole, J.J. and N.F. Caraco. 1998. Atmospheric exchange of carbon dioxide in a low-wind oligotrophic lake measured by the addition of $\mathrm{SF}_{6}$. Limnology and Oceanography 43(4): 
647-656.

Cole, J.J., N.F. Caracao, G.W. Kling, and T.K. Kratz. 1994. Carbon dioxide supersaturation in the surface waters of lakes. Science 265: 1568-1570.

Columbia Basin Research (CBR). 2013. Lower Monumental Dam: Hydroelectric Project Information. Available at http://www.cbr.washington.edu/hydro/priestrapids and http://www.cbr.washington.edu/hydro/lowermonumental. Accessed on March 13, 2013.

Columbia River Data Access in Real Time (DART). 2013. DART River Environment. Available at: http://www.cbr.washington.edu/dart/river.html. Accessed on January 25, 2013.

Crusius, J. and R. Wanninkhof. 2003. Gas transfer velocities measured at low windspeed over a lake. Limnology and Oceanography 48(3): 1010-1017.

Del Sontro, T., D.F. McGinnis, S. Sobek, I. Ostrovsky, B. Wehrli. 2010. Extreme methane emissions from a Swiss hydropower reservoir: Contribution from bubbling sediments. Environmental Science and Technology 44: 2419-2425.

Duchemin, E., Lucotte, M., and Caneul, R. 1999. Comparison of static chamber and thin boundary layer equation methods for measuring greenhouse gas emissions from large water bodies. Environmental Science and Technology 33: 350-357.

Forster, P., V. Ramaswamy, P. Artaxo, T. Berntsen, R. Betts, D.W. Fahey, J. Haywood, J. Lean, D.C. Lowe, G. Myhre, J. Nganga, R. Prinn, G. Raga, M. Schulz and R. Van Dorland. 2007. Changes in atmospheric constituents and in radiative forcing. In: Solomon, S., D. Qin, M. Manning, Z. Chen, M. Marquis, K.B. Averyt, M.Tignor and H.L. Miller (eds.). Climate change 2007: The physical science basis. Contribution of working group I to the fourth assessment report of the Intergovernmental Panel on Climate. Cambridge University Press, Cambridge, United Kingdom and New York, NY.

Furrer, G. and B. Wehrli. 1996. Microbial reactions, chemical speciation, and multicomponent diffusion in porewaters of a eutrophic lake. Geochimica et Cosmochimica Acta 60(13): $2333-2346$.

Galy-Lacaux, C., R. Delmas, C. Jambert, J. Dumestre, L. Labroue, S. Richard, and P. Gosse. 1997. Gaseous emissions and oxygen consumption in hydroelectric dams: A case study in French Guiana. Global Biogeochemical Cycles 11: 47-483.

Guerin, F., G. Abril, S. Richard, B. Burban, C. Reynouard, P. Seyler, and R. Delmas. 2006. Methane and carbon dioxide emissions from tropical reservoirs: Significance of downstream reservoirs. Geophysical Research Letters 33: doi:10.1029/2006GL027929.

Guy, H.P. 1969. Laboratory theory and methods for sediment analysis. In: U.S. Geological Survey (ed.), Techniques of water resources investigations of the United States Geological Survey. U. S. Government Printing Office, Washington, D.C. 
Heiri O., A.F. Lotter, and G. Lemcke. 2001. Loss on ignition as a method for estimating organic and carbonate content in sediments: Reproducibility and comparability of results. Journal of Paleolimnology 25: 101-110.

Huttunen, J.T., T.S. Vaisanen, S.K. Hellsten, and P.J. Martikainen. 2006. Methane fluxes at the sediment-water interface in some boreal lakes and reservoirs. Boreal Environmental Research 11: 27-34.

Intergovernmental Panel on Climate Change (IPCC). 2007. Climate change 2007: The scientific basis. Contribution of Working Group I to the Fourth Assessment Report of the Intergovernmental Panel on Climate Change, ed. S. Solomon et al., Cambridge University Press, New York.

International Hydropower Association, United Nations Education, Scientific, and Cultural Organzation. 2010. GHG Measurement guidelines for freshwater reservoirs. IHA London.

Jaehne, B., G. Heinz, and W. Dietrich. 1987. Measurement of the diffusion coefficients of sparingly soluble gases in water. Journal of Geophysical Research 92: 10767-10776.

Juutinen, S., J. Alm, T. Larmola, J.T. Huttunen, K. Moreo, P.J. Martikainen, and J. Silvola. 2003. Major implication of the boreal zone for methane release from boreal lakes. Global Biogeochemical Cycles 17: doi:10.1029/2003GB002105.

Kankaala, P., T. Kaki, S. Makela, A. Ojala, H. Pajunen, and L. Arvola. 2005. Methane efflux in stands of three common emergent macrophytes in boreal mesoeutrophic lakes. Global Change Biology 11: 145-153.

Kelker, D. and J. Chanton. 1997. The effect of clipping on methane emissions from Carex. Biogeochemistry 39: 37-44.

Lide, D.R. 2007. CRC Handbook of Chemistry and Physics, $88^{\text {th }}$ Ed. CRC Press, New York.

MacIntyre, S., R. Wanninkhof, and J.P. Chanton. 1995. Trace gas exchange across the air-water interface in freshwater and coastal marine environments. In Freshwater and coastal marine environments, P.A. Matson and Harris (eds.). Blackwell Science, Hoboken, New Jersey.

Morel, F.M.M. and J.G. Hering. 1993. Principles and Applications of Aquatic Chemistry. John Wiley and Sons, Inc., New York, NY. 
Mulholland, P., J. Mosher, A. Fortner, J. Phillips, and M. Bevelhimer. 2010. Greenhouse gas emissions from U.S. hydropower reservoirs. Submitted to the Wind and Water Power Technologies Program, Office of Energy Efficiency and Renewable Energy, U.S. Department of Energy.

Nuernberg, G. 2004. Quantified hypoxia and anoxia in lakes and reservoirs. Freshwater Research 4: 42-54.

ORNL (Oak Ridge National Laboratory). 2013. National Hydropower Asset Assessment Project (NHAAP) Database.

Papadimitriou, S., H. Kennedy, I. Bentalen, and D.N. Thomas. 2002. Dissolved organic carbon in sediments from the eastern North Atlantic. Marine Chemistry 79: 37-47.

Roehm, C. and A. Tremblay. 2006. Role of turbines in the carbon dioxide emissions from two reservoirs. Journal of Geophysical Research Atmospheres 111(D24): DOI: $10.1029 / 2006 J D 007292$

Santos, M., B. Matvienko, L. Rosa, L. Sikar, and E. Santos. 2005. Gross greenhouse gas emissions from Brazilian hydro reservoirs. In: Tremblay, A., L. Varfalvy, C. Roehm, and M. Garneau (eds.). Greenhouse gas emissions: Fluxes and processes, hydroelectric reservoirs and natural environments. Environmental Science Series, Springer, New York, NY.

Schindler, J.E. and D.P. Krabbenhoft. 1998. The hyporheic zone as a source of dissolved organic carbon and carbon gases to a temperate forested stream. Biogeochemistry 43: 157-174.

Seybold WF and DH Bennett. 2010. Inventory and Impact/Benefit Analyses of Sediment Disposal for Salmonid Fishes at Selected Sites in the Lower Snake River Reservoirs, Washington. U.S. Army Corps of Engineers, Walla Walla District, Walla Walla, Washington.

Soumis, N., E. Duchemin, R. Canuel, and M. Lucotte. 2004. Greenhouse gas emissions from reservoirs of the western United States. Global Biogeochemical Cycles 18: GB3022

St. Louis, V.L., Kelly, C.A., Duchemin, E., Rudd, J.W.M. and Rosenberg, D.M. 2000. Reservoirs surfaces as sources of greenhouse gases to the atmosphere: A global estimate. BioScience 50: 766-775.

Stephens, D.B., K.C. Hsu, M.A. Prieksat, M.D. Ankeny, N. Blandford, T.L. Roth, J.A. Kelsey, J.R. Whitworth. 1998. A comparison of estimated and calculated effective porosity. Hydrogeology Journal 6: 156-165.

Strayer, R.F. and J.M. Tiedje. 1978. In situ methane production in a small, hypereutrophic, hard-water lake: Loss of methane from sediments by vertical diffusion and ebullition. Limnology and Oceanography 23(6): 1201-1206. 
Sweerts, J.R.A., M. Bar-Gilissen, A.A. Cornelese, and T.E. Cappenberg. 1991. Oxygenconsuming processes at the profundal and littoral sediment-water interface of a small meso-eutrophic lake (Lake Vecten, The Netherlands). Limnology and Oceanography 36(6): 1124-1133.

Taub, D. 2010. Effects of rising atmospheric concentrations of carbon dioxide on plants. Nature Education Knowledge 3(10): 21.

Therrien, J., Tremblay, A. and Jacques, R. 2005. $\mathrm{CO}_{2}$ emissions from semi-arid reservoirs and natural aquatic ecosystems. In Tremblay, A., L. Varfalvy, C. Roehm et M. Garneau (eds.). Greenhouse gas emissions: Fluxes and processes, hydroelectric reservoirs and natural environments. Environmental Science Series, Springer, Berlin, Germany, Heidelberg, Germany, and New York, NY.

Tremblay, A., L. Varfalvy, C. Roehm, M. Garneau. 2005. Greenhouse gas emissions: Fluxes and processes, hydroelectric reservoirs and natural environments. Springer, Berlin, Germany, Heidelberg, Germany, and New York, NY.

USACE (U.S. Army Corps of Engineers). 2012. Watermanagement anonymous FTP site. USACE, Northwestern Division Civil Works and Management Directorate, Columbia Basin Water Management Division. Available: www.nwdwc.usace.army.mil/ftppub/water_quality/12data/. (January 2013).

U.S. Geological Survey (USGS). 2013. National Water Information System. Available at: http://nwis.waterdata.usgs.gov/usa/nwis/uv/?cb 00060=on\&cb_00065 =on\&format=gif_s tats\&period=\&begin_date $=2012-01-01 \&$ end date $=2013-01-01 \&$ site $\_$no $=12472800$. Accessed January 1, 2013.

Wanninkhof, R. 1992. Relationship between wind speed and gas exchange over the ocean. Journal of Geophysical Research 97: 7373-7382.

Weiss, R.F. 1974. Carbon dioxide in water and seawater: The solubility of a non-ideal gas. Marine Chemistry 2: 203-215.

Wiesenburg, D.A. and N.L. Guinasso. 1979. Equilibrium solubilities of methane, carbon monoxide, and hydrogen in water and sea water. Journal of Chemical and Engineering Data 24(4): 356-360.

Wilhelm, E., R. Battino, and R.J. Wilcox. 1977. Low-pressure solubility of gases in liquid water. Chemical Reviews 77(2): 219-262.

Wetzel, R.G. 2001. Limnology: Lake and river ecosystems. Academic Press, San Diego, CA and London, United Kingdom.

Yamamoto, S., J.B. Alcauskas, and T.E. Crozier. 1976. Solubility of methane in distilled water and seawater. Journal of Chemical and Engineering Data 21(1): 78-80. 


\section{Appendix A}

\section{Study Site Locations \\ (electronic file submitted to DOE)}




\section{Appendix B}

Gas Concentrations and Flux Data (electronic file submitted to DOE) 


\section{Appendix C}

\section{Gas Concentrations and Flux Summary Tables (electronic file submitted to DOE)}




\title{
Appendix D
}

\author{
Water Quality Data \\ (electronic file submitted to DOE)
}




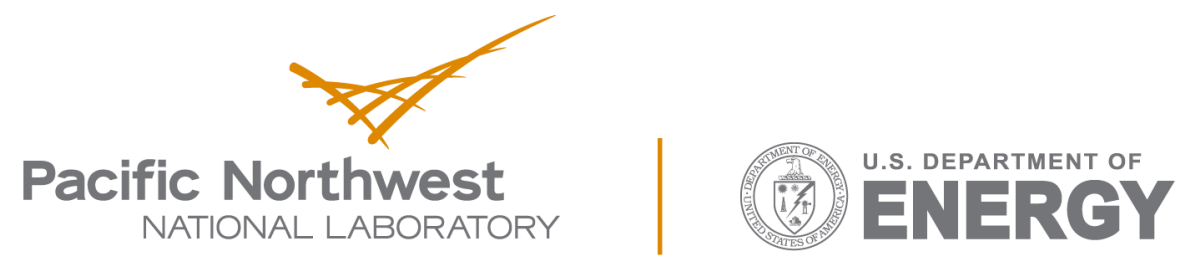

Proudly Operated by Battelle Since 1965

902 Battelle Boulevard

P.O. Box 999

Richland, WA 99352

1-888-375-PNNL (7665)

www.pnnl.gov 